\title{
Carbon and nutrient export regimes from headwater catchments to downstream reaches
}

\author{
Rémi Dupas $^{1,5}$, Andreas Musolff ${ }^{2}$, James W. Jawitz ${ }^{3}$, P. Suresh C. Rao ${ }^{4}$, Christoph G. Jäger ${ }^{1}$, Jan H. Fleckenstein ${ }^{2}$, \\ Michael Rode ${ }^{1}$, and Dietrich Borchardt ${ }^{1}$ \\ ${ }^{1}$ Department of Aquatic Ecosystems Analysis and Management, Helmholtz Centre for Environmental Research UFZ, \\ Magdeburg, Germany \\ ${ }^{2}$ Department of Hydrogeology, Helmholtz Centre for Environmental Research UFZ, Leipzig, Germany \\ ${ }^{3}$ Soil and Water Science Department, University of Florida, Gainesville, Florida, USA \\ ${ }^{4}$ School of Civil Engineering and Department of Agronomy, Purdue University, West Lafayette, Indiana, USA \\ ${ }^{5}$ INRA, UMR1069 SAS, 35000 Rennes, France
}

Correspondence to: Rémi Dupas (remi.dupas@inra.fr)

Received: 14 March 2017 - Discussion started: 10 May 2017

Revised: 1 September 2017 - Accepted: 5 September 2017 - Published: 29 September 2017

\begin{abstract}
Excessive amounts of nutrients and dissolved organic matter in freshwater bodies affect aquatic ecosystems. In this study, the spatial and temporal variability in nitrate $\left(\mathrm{NO}_{3}^{-}\right)$, dissolved organic carbon (DOC) and soluble reactive phosphorus (SRP) was analyzed in the Selke (Germany) river continuum from three headwaters draining $1-3 \mathrm{~km}^{2}$ catchments to two downstream reaches representing spatially integrated signals from $184-456 \mathrm{~km}^{2}$ catchments. Three headwater catchments were selected as archetypes of the main landscape units (land use $\times$ lithology) present in the Selke catchment. Export regimes in headwater catchments were interpreted in terms of $\mathrm{NO}_{3}^{-}$, DOC and SRP land-to-stream transfer processes. Headwater signals were subtracted from downstream signals, with the differences interpreted in terms of in-stream processes and contributions from point sources. The seasonal dynamics for $\mathrm{NO}_{3}^{-}$were opposite those of DOC and SRP in all three headwater catchments, and spatial differences also showed $\mathrm{NO}_{3}^{-}$contrasting with DOC and SRP. These dynamics were interpreted as the result of the interplay of hydrological and biogeochemical processes, for which riparian zones were hypothesized to play a determining role. In the two downstream reaches, $\mathrm{NO}_{3}^{-}$was transported almost conservatively, whereas DOC was consumed and produced in the upper and lower river sections, respectively. The natural export regime of SRP in the three headwater catchments mimicked a point-source signal (high SRP during summer low flow), which may lead to overestimation of do-
\end{abstract}

mestic contributions in the downstream reaches. Monitoring the river continuum from headwaters to downstream reaches proved effective to jointly investigate land-to-stream and instream transport, and transformation processes.

\section{Introduction}

Riverine exports are a key component in the global biogeochemical cycles of carbon $(\mathrm{C})$, nitrogen $(\mathrm{N})$ and phosphorus (P) (Beusen et al., 2016). River export regimes of their dominant soluble forms, dissolved organic C (DOC), nitrate-N $\left(\mathrm{NO}_{3}^{-}\right)$and soluble reactive $\mathrm{P}(\mathrm{SRP})$, result from the interplay of land-to-stream diffuse transfer processes and in-stream transformations, and can be altered by point-source contributions (Seitzinger et al., 2010). Excess delivery of DOC, $\mathrm{NO}_{3}^{-}$and SRP into sensitive water-bodies affects ecosystem structure and functions, and elemental stoichiometric ratios have been shown to be of major importance (Sardans et al., 2012). Therefore, detailed knowledge of the catchment processes controlling the spatial and temporal variability in the delivery of DOC, $\mathrm{NO}_{3}^{-}$, SRP and stoichiometric ratios at relevant management scales, e.g., the European Union Water Framework Directive (EC, 2000) water-bodies, is a prerequisite for designing effective water pollution mitigation programs (Wall et al., 2011). 
Water-quality assessment programs performed by environmental agencies typically focus on relatively large $\left(>100 \mathrm{~km}^{2}\right)$ catchments, to increase spatial coverage within a given hydrographic basin or administrative unit, while reducing the density of monitoring stations and thus the cost (Bouraoui and Grizzetti, 2011; Dupas et al., 2015a). However, large catchments include both diffuse and domestic or industrial point-source contributions and possibly various landscape units. Thus, the water-quality signal measured at the outlet integrates several transfer mechanisms contributing to emissions in the river network, as well as in-stream processes (Grathwohl et al., 2013). Therefore, it is difficult to decipher the diffuse contributions of different landscape units from point-source contributions and instream transformations (Bishop et al., 2008; Temnerud et al., 2016). In contrast to environmental agency monitoring programs, scientific programs often focus on headwater catchments free of point-sources and with relatively homogeneous landscape types (Fealy et al., 2010; McGonigle et al., 2014), where in-stream processes are often considered to be minimal (Salmon-Monviola et al., 2013). A comparison of export regimes in contrasting catchments representing different landscape types can be performed to investigate the effect of, for example, contrasting dominant land use, dominant flow paths or climate (Outram et al., 2014; Dupas et al., 2017; Minaudo et al., 2017), sometimes aided by the use of models (e.g., Dupas et al., 2016a; Hartmann et al., 2016). In headwater catchments, several studies have highlighted the important role of landscape heterogeneity within hillslopes (Herndon et al., 2015; Musolff et al., 2017), notably the crucial role of reactive zones such as riparian wetlands (Dick et al., 2015; Pinay et al., 2015; Tiwari et al., 2017) in controlling solute export regimes.

To upscale headwater signals to downstream reaches, previous landscape mixing models, i.e., "models mixing headwater signals in proportion to their patch coverage" (Tiwari et al., 2017), often lack consideration of temporal variability in headwater signals and explicit consideration of in-stream transformations (e.g., Laudon et al., 2011; Agren et al., 2014). Few opportunities exist to study the export regimes of several headwater catchments representing "archetypes" of the main landscape units in a larger catchment, for multiple solutes and on different time scales, and to compare headwater export regimes to the integral signal measured in downstream reaches. Monitoring data from the Bode catchment $\left(3300 \mathrm{~km}^{2}\right)$, part of the hydrological Harz/Central German Lowland Observatory in the Helmholtz Association Terrestrial Environmental Observatories (TERENO) network (Zacharias et al., 2011), offers such opportunities and it was this catchment that is taken as a case study in this paper.

In this paper we hypothesized that the land use and lithology characteristics of the landscape units identified control export regimes in headwaters, and that in-stream processes and point-source contributions alter export regimes in downstream reaches. We also hypothesized that spatial and tem- poral variability in solute concentrations could lead to variability in $\mathrm{N}$ and $\mathrm{P}$ limitation in streams and rivers.

The main objective of this paper, therefore, was to characterize the spatial and temporal variability in $\mathrm{NO}_{3}^{-}, \mathrm{DOC}$ and SRP export regimes from archetypal headwater catchments to downstream reaches, and to analyze the resulting nutrient stoichiometric ratios. Export regimes in headwater catchments are used for interpretation of land-to-stream $\mathrm{NO}_{3}^{-}$, DOC and SRP transfer processes and compared with those in downstream reaches to infer in-stream processes and pointsource contributions.

\section{Materials and methods}

\subsection{Study area}

The Bode catchment $\left(3300 \mathrm{~km}^{2}\right)$ is located in the German part of the Elbe river basin $\left(144055 \mathrm{~km}^{2}\right)$ (Zacharias et al., 2011). The Bode catchment stretches from the Harz mountains, a low mountain range in central Germany (maximum altitude 1142 ma.s.l.), to the central German lowlands, a flat and fertile area dedicated to arable agriculture (altitude around 100 ma.s.1.). This topographic gradient coincides with gradients of climate, geology, soil and land use pressures (Wollschlager et al., 2016). Long-term mean annual (1951-2011) precipitation and temperature in the Bode catchment ranges from $1700 \mathrm{~mm}$ and $5^{\circ} \mathrm{C}$ in the Harz mountains to $500 \mathrm{~mm}$ and $9.5^{\circ} \mathrm{C}$ in the lowland area, with the lowest and highest temperatures in January and July, respectively, (Wollschlager et al., 2016). The Selke tributary catchment $\left(456 \mathrm{~km}^{2}\right)$ was selected for study here as it encompasses the different combinations of land use and lithology present in the Bode catchment and it has been intensively monitored since 2010. Other varying environmental factors, such as soil type, climate and dominant farming systems, coincide with the topographic gradient reflected in the differentiation according to lithology.

The $456 \mathrm{~km}^{2}$ Selke catchment (Fig. 1) comprises upper and lower portions. The upper Selke $\left(184 \mathrm{~km}^{2}\right)$, monitored at Meisdorf station (MEIS), is located in the Harz mountains (209-595 ma.s.1.). The dominant soil type is Cambisol overlaying impervious schist and claystone, resulting in a dominance of shallow flow pathways (Jiang et al., 2014b). These shallow groundwater systems favor the development of hydromorphic riparian soils (periodically waterlogged soils near the streams, delineated in this study according to a soil map), representing $10 \%$ of the surface area. The land use is dominated by $73 \%$ forest (including broadleaved, coniferous and mixed forest) followed by $25 \%$ agriculture (mainly arable crops: winter cereals, rapeseed and maize). Artificial surfaces cover the remaining $2 \%$. The upper Selke catchment also includes three wastewater treatment plants with 9300 equivalent inhabitants. The lowland area of the lower Selke $\left(272 \mathrm{~km}^{2}\right)$ is a fertile plain (62-209 ma.s.1.) 


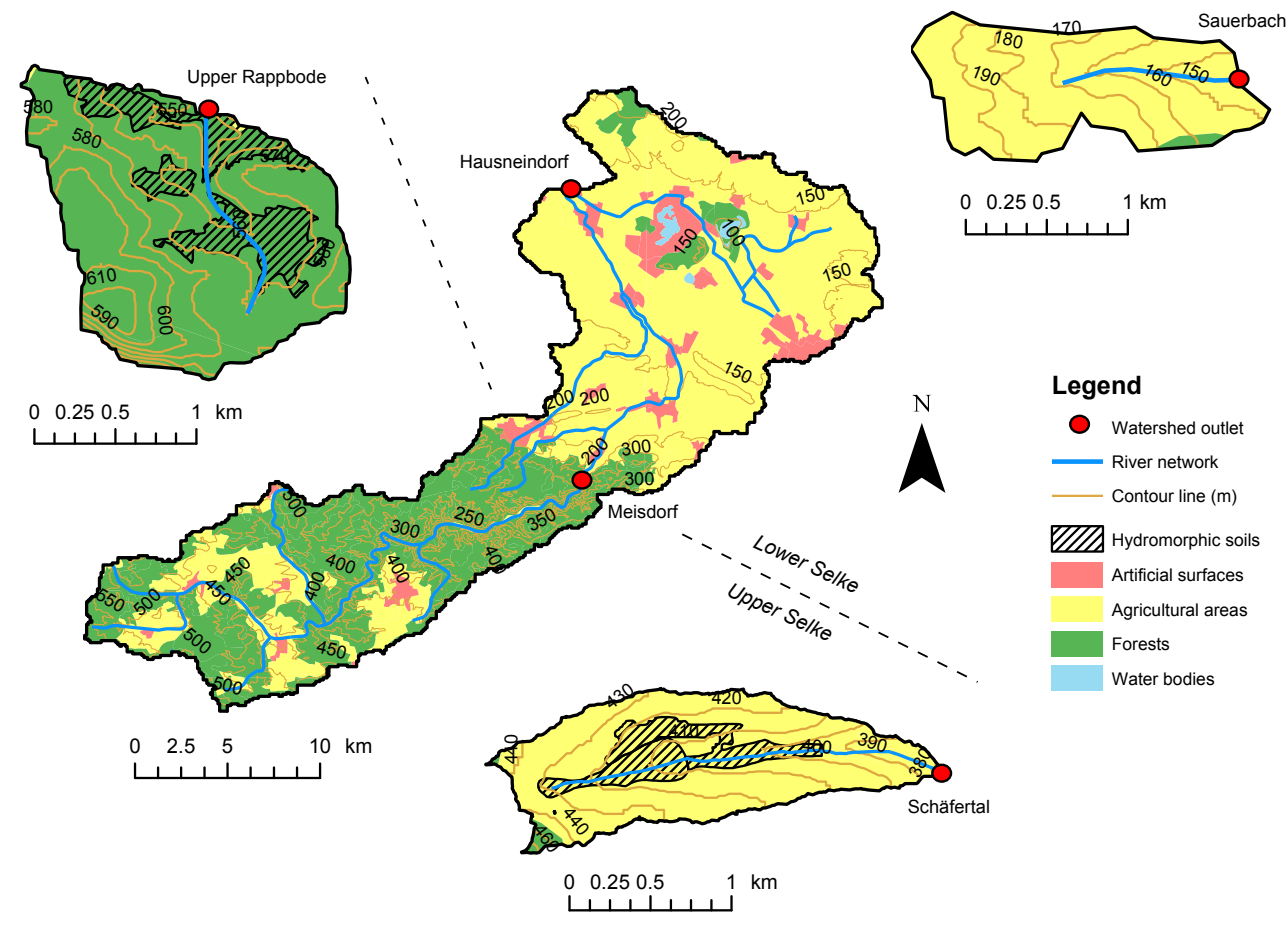

Figure 1. Landscape types in the Selke catchment and location of monitoring sites.

dominated by chernozems overlaying non-metamorphic sedimentary rocks (sandstones and limestones) partly covered by loess. The downstream monitoring station at Hausneindorf (HAUS) integrates the combined influence of the upper and lower Selke. Hydrology in the lowland area is dominated by deeper groundwater flows (Jiang et al., 2014b); soils classified as hydromorphic represent only $3 \%$ of the surface area. The land use is dominated by $81 \%$ agriculture (mainly arable crops: winter cereals, rapeseed, maize and sugar beet) followed by $10 \%$ forest. The remaining $9 \%$ comprises artificial surfaces and small lakes. The lowland area includes two wastewater treatment plants with 10600 equivalent inhabitants. More than $95 \%$ of the population in the Selke catchment is connected to a wastewater treatment plant (Rode et al., 2016a).

In addition to these two stations located on the Selke river, the Harz/Central German Lowland Observatory also includes monitoring of $1-3 \mathrm{~km}^{2}$ headwater catchments representing the dominant main landscape units (i.e., combinations of land use $\times$ lithology) present in the Selke and Bode catchments (Fig. S1 in the Supplement). The Schäfertal $\left(1.44 \mathrm{~km}^{2}\right)$ is representative of an agricultural catchment in the upper Selke. Its elevation ranges between 379 and 466 ma.s.l., $19 \%$ of the surface area consists of hydromorphic riparian soils and $98 \%$ of the land use is arable agriculture (only $2 \%$ forest). The upper Rappbode $\left(2.58 \mathrm{~km}^{2}\right)$ is representative of a forested catchment in the upper Selke. Its elevation ranges between 542 and 619 ma.s.l., $19 \%$ of the surface area consists of hydromorphic riparian soils and $100 \%$ of the land use is forest. The Sauerbach $\left(1.37 \mathrm{~km}^{2}\right)$ is representative of an agricultural catchment in the lower Selke. Its elevation ranges between 144 and 200 ma.s.1., $100 \%$ of the surface area consists of well-drained soils and $98 \%$ of the land use is arable agriculture (only $2 \%$ forest).

In this study the three headwater catchments are considered as "archetypes" of the different landscape units (land use $\times$ lithology) in the Selke catchment. All three headwater catchments are located in the $3300 \mathrm{~km}^{2}$ Bode catchment of the TERENO Harz/Central German Lowland Observatory, but only US-Agr is a sub-catchment of the Selke; US-For and LS-Agr are nearby sub-catchments of the Bode (distance from the Selke catchment: 13 and $20 \mathrm{~km}$, respectively) and are considered representative of headwater catchments in the Selke catchment. Schäfertal and upper Rappbode represent respectively agricultural and forested areas in the Harz mountains, i.e., the fraction of the Selke catchment upstream of the MEIS station. Schäfertal and upper Rappbode are termed thereafter "US-Agr" and "US-For" for "Upper Selke - Agriculture" and "- Forest", respectively. Sauerbach represents agricultural land use in the lowland part of the catchment, i.e., the dominant landscape between the MEIS and HAUS stations. Sauerbach is termed hereafter "LS-Agr" for "Lower Selke - Agriculture". Minor landscape types (e.g., forest in lowland area) are neglected.

Table S1 in the Supplement summarizes the main characteristics of all five study catchments. 


\subsection{Monitoring strategy}

Discharge and water quality were monitored comparably at the outlet of the two large catchments (MEIS and HAUS) and three headwater catchments (US-Agr, US-For and LSAgr). At MEIS and HAUS, discharge data were measured by the hydrological state authority of Saxony-Anhalt (Landesbetrieb für Hochwasserschutz und Wasserwirtschaft) at 15 min intervals. Water quality was sampled as part of the TERENO program biweekly from June 2010 to September 2013 and monthly from October 2013 to December 2015, complemented by high-frequency sampling during eight storm events at MEIS and seven storm events at HAUS (2 to $4 \mathrm{~h}$ interval, ISCO 6700 autosampler).

In US-Agr, discharge was measured every $15 \mathrm{~min}$ at a gauging station with a water level sensor upstream of a Vnotch weir. Manual grab samples were collected biweekly to monthly from March 1999 to September 2010, complemented by high-frequency sampling during eight storm events ( $20 \mathrm{~min}$ to $1 \mathrm{~h}$ interval, ISCO 6700 autosampler). In US-For, discharge was measured every $10 \mathrm{~min}$ using a Solinst LTC data logger and external barometric measurements. Manual grab samples were collected biweekly from March 2013 to October 2015 and no high-frequency monitoring of storm events has been performed in this catchment. In LS-Agr, discharge was measured every $10 \mathrm{~min}$ at a gauging station with a pressure logger (ecoTech PDL) upstream of a triangular weir ( $\mathrm{V}$-notch weir). Manual grab samples were collected biweekly to monthly from June 2010 to December 2015, complemented by high-frequency sampling during four storm events (20 min to $1 \mathrm{~h}$ interval, ISCO $6700 \mathrm{au}-$ tosampler).

All samples were filtered in the field using $0.45 \mu \mathrm{m}$ cellulose acetate filters and kept cool until analysis within 2 days. Nitrate concentration was determined by ion chromatography (ICS-2000, Dionex), DOC was determined with a carbon analyzer (TOC 5050, Shimadzu) and SRP was determined colorimetrically by reaction with ammonium molybdate. Samples from all five catchments were analyzed following the same protocol and in the same laboratory at UFZ Magdeburg. An exception to this standardized protocol was measurement of total phosphorus (TP) in US-For; to convert TP into SRP and allow comparison with the other catchments, the mean SRP/TP ratio of 0.42 , established in 55 forested catchments throughout Germany (Musolff et al., 2016b), was used (standard deviation of the SRP/TP ratio was 0.19 , reflecting relatively small variability).

\subsection{Data analysis}

Solute export regimes for DOC, $\mathrm{NO}_{3}^{-}$and SRP were characterized on an intra-annual basis (seasonal variability) and for discrete storm events. The term "solute export regime" was chosen by analogy with the hydrological definition of river regimes, i.e., the variability in a river discharge through- out the course of a year in response to precipitation, temperature, evapotranspiration and drainage basin characteristics (Beckingsale, 1969). The reference study period in this analysis was June 2010-December 2015, i.e., the period when data were available in the two stations situated in the main Selke river (MEIS and HAUS) and in LS-Agr. The US-Agr catchment was monitored prior to the establishment of the TERENO observatory (March 1999-September 2010). The US-For catchment was not part of the permanent TERENO monitoring, so this catchment was monitored for 20 months for this study (March 2013-October 2014). The different monitoring periods in two of the headwater catchments were assumed to have minimal effect on mean annual concentration and seasonal variability, due to the well-documented biogeochemical stationarity in catchments (Basu et al., 2010; Humbert et al., 2015; Godsey et al., 2009) resulting in consistent annual patterns of solute concentrations despite potentially large interannual variability in the hydroclimate. This biogeochemical stationarity can be verified with the 10 year record in the US-Agr catchment (Fig. S2) and in the comparison of discharge and solute variability (Sect. 3.1). The same assumption cannot be made for discharge due to interannual climate variability.

Figure S3 summarizes the main steps of the data analysis.

\subsubsection{Discharge and concentration variability}

First, river flow regimes were characterized in all five study catchments after aggregation of discharge data on a monthly basis. Second, to quantify the overall variability of discharge (daily) and concentration data (grab sampling), the coefficients of variation $(\mathrm{CV})$ for both discharge and concentrations were calculated for each study catchment and for each year. The coefficient of variation, defined as the ratio of the standard deviation to the mean of a variable, has been used for the same purpose in previous water quantity (Botter et al., 2013) and water quality studies (Dupas et al., 2016b; Musolff et al., 2015; Thompson et al., 2011). Finally, correlation coefficients were calculated between solute concentrations and discharge and between pairs of solute concentrations. The Spearman rank correlation coefficient was used because relations between pairs of variables are not necessarily linear (Thomas et al., 2016).

\subsubsection{Seasonal variability in concentrations and stoichiometric ratio}

Grab sampling data were used to fit a periodic equation to the data in all five study catchments:

Concentration $=a+b \cdot \cos (2 \pi / i+c)$.

In Eq. (1), $a$ is an estimate of the mean concentration, $b$ is an estimate of the seasonal amplitude, $c$ is a phase coefficient to identify seasonal maximum and $i$ is the Julian day. In addition, the coefficient of determination $R^{2}$ was calcu- 
lated to quantify the percentage of the variance explained by a periodic signal (i.e., the seasonal variation) and the $b / a$ ratio was calculated as an estimate of the relative amplitude of the seasonal variation. The periodic equation was not fitted to the discharge data because: (i) daily discharge data does not exhibit a clear cosine shape (due to storm events) and (ii) interannual climate variability results in varying seasonal amplitudes from year to year (data not shown).

In this study, the influence of in-stream processes and point-source contributions was inferred by the difference between the observed export regimes in downstream reaches and the export regimes that would have been expected if the integral downstream signal consisted of a "conservative mixing" of the export regimes observed in the archetypal headwater catchments. The "conservative mixing" method to simulate the export regime for MEIS consisted in a surface area weighted averaging of US-Agr and US-For export regimes; we chose not to use observed discharge as a weighting factor because both headwater catchments have been monitored during different periods. The "conservative mixing" method to simulate the export regime for HAUS consisted in a weighted averaging of MEIS and LS-Agr export regime, with a weighting factor being the discharge measured at MEIS and the difference between discharges measured in HAUS and MEIS (assuming that this difference represented the contribution of the lowland area, with a concentration export regime represented by LS-Agr). For HAUS, we used discharge as a weighting factor because both MEIS and HAUS have been monitored during the same period.

The potential ecological impacts of the observed seasonal variability in concentrations on different spatial scales are discussed in terms of nutrient stoichiometric ratios. Keck and Lepori (2012) have reviewed 382 nutrient-enrichment experiments to examine which factors promote limitation of micro-phytobenthos biomass by $\mathrm{N}$ or $\mathrm{P}$. They found that prediction of $\mathrm{N}$ or $\mathrm{P}$ limitation was highly uncertain, except at extreme $\mathrm{N}: \mathrm{P}$ molar ratios less than $1: 1$ and greater than $100: 1$. Other studies have considered a narrower range of $\mathrm{N}$ : P molar ratios to assess possible co-limitation: for example McDowell et al. (2009) considered that N-P co-limitation could take place for $\mathrm{N}: \mathrm{P}$ molar ratios between $16: 1$ and $32: 1$. In this study we considered both the large interval of Keck and Lepori (2012) and the narrower interval of McDowell et al. (2009) to evaluate possible N-P co-limitation; hence both thresholds $100: 1$ and $32: 1$ were considered.

\subsubsection{Storm event response}

High-frequency autosampler data were used to calculate the linear slope of the concentration-discharge $(C-Q)$ relations during discrete storm events. A $p$ value of 0.05 was used as a threshold for each event to have a significant positive slope (accretion pattern) and negative slope (dilution pattern). The linear slopes of the $C-Q$ relations were calculated for all storm events in the MEIS, HAUS, US-Agr and LS-
Agr catchments; because the US-For catchment was not part of the permanent TERENO monitoring, no high-frequency autosampler data were available in this catchment. The mixing model was not applied to storm event export regimes because rainfall could be very localized in the study area, hence a mixing model applied to storm events would require precise knowledge of the spatial distribution of rainfall over the different landscape archetypes for each event, which is beyond the scope of this paper.

\section{Results}

\subsection{Discharge and concentration variability}

Seasonal variability in discharge exhibited high-flow periods both during the spring and the autumn-winter period, which is characteristic of a nivo-pluvial (Beckingsale, 1969) river regime (Fig. 2). In the headwater catchments (Fig. 2a), a higher seasonal variability in discharge was observed in the two catchments located in the Harz mountains, representing the upper Selke (US-Agr and US-For), compared to the catchment located in the lowland area (LS-Agr). This difference in seasonal discharge can be explained both by the climate gradient, with higher snowfall in the Harz mountains compared to the lowland area, and by the different lithology, which results in a flashier river regime in the upper Selke compared to the lower Selke (Jiang et al., 2014b). The same conclusions hold true when observing seasonal discharge variability at the downstream stations of MEIS and HAUS (Fig. 2b), namely with a higher variability in the upper Selke than in the lower Selke. The coefficient of variation of daily discharge $\mathrm{CV}_{Q}$ (Table 1) was also higher in catchments representing the upper Selke (on average 2.32, 1.25 and 1.23 in US-Agr, US-For and MEIS, respectively) than in the lower Selke (on average 0.22 and 0.99 in LS-Agr and HAUS, respectively).

In a large majority of situations (all three solutes in US-Agr, US-For, MEIS and HAUS, and $\mathrm{NO}_{3}^{-}$in LS-Agr), $\mathrm{CV}_{\mathrm{C}} \ll \mathrm{CV}_{Q}$ (Table 1), which reveals a biogeochemical stationarity termed "chemostasis" in previous catchments studies (Basu et al., 2010; Musolff et al., 2015; Godsey et al., 2009). Only SRP and DOC in the LS-Agr catchment exhibited a higher coefficient of variation than discharge (Table 1).

\subsection{Seasonal variability in concentrations and stoichiometric ratio}

The mean concentration observed in the three headwater catchments (quantified by the " $a$ " parameter in Table 2) was in the order US-For $<$ US-Agr $<\mathrm{LS}$-Agr for $\mathrm{NO}_{3}^{-}$, and LSAgr $<$ US-Agr $\approx$ US-For for DOC and SRP (Fig. 3a). The seasonal amplitude of the periodic function (quantified by its absolute value " $b$ " or relative value " $b / a$ " in Table 2 ) was higher in US-Agr and US-For than in LS-Agr for all three solutes. Consistent with the higher seasonal amplitude 

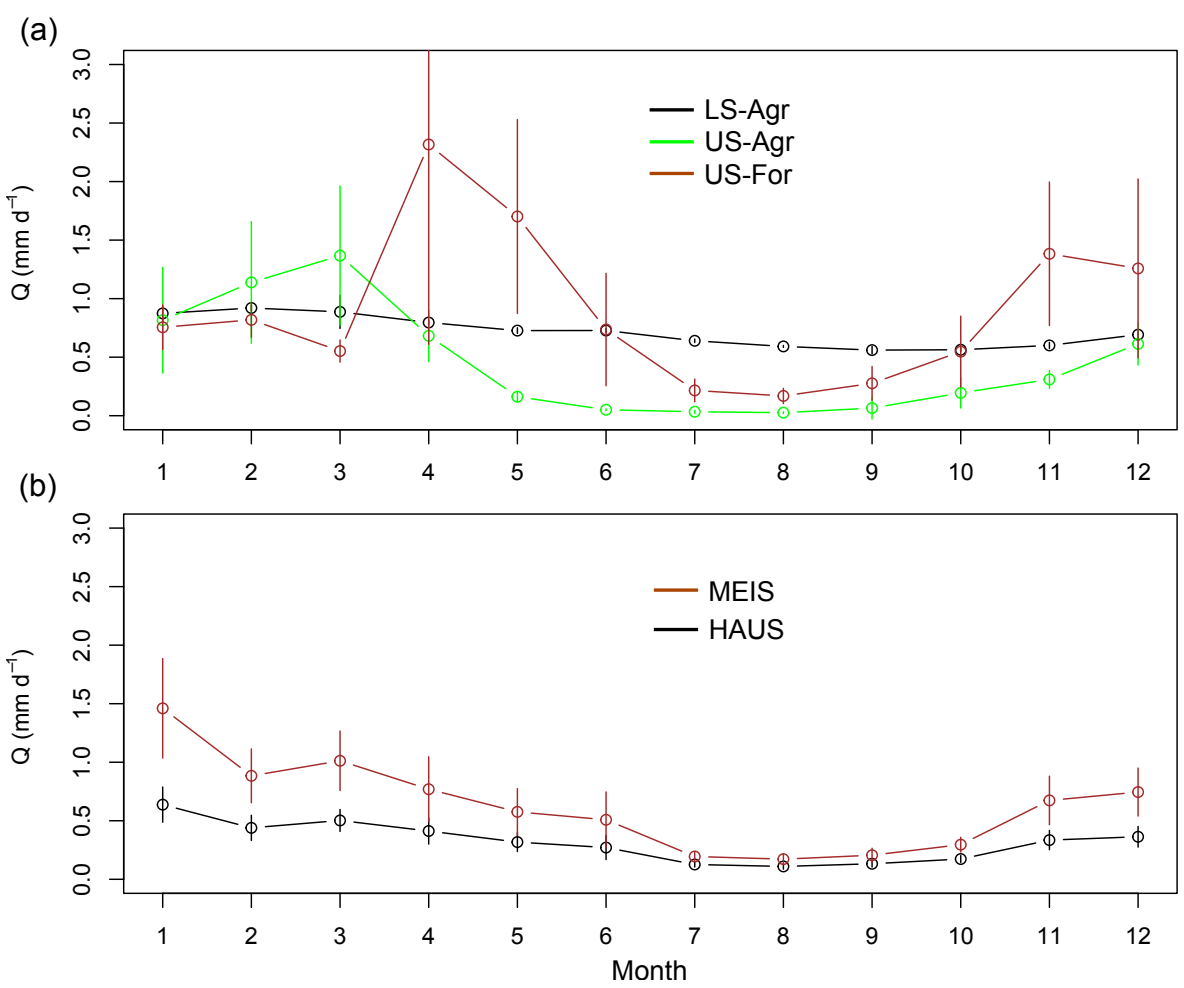

Figure 2. Monthly discharge in headwater catchments (a) and downstream catchments (b). Error bars represent the standard deviation $(n=2-10$ years $)$.

Table 1. Coefficient of variation (CV; mean \pm standard deviation, $n=2-10$ years) of daily discharge (Q), concentrations and $\mathrm{N}$ : $\mathrm{P}$ ratio.

\begin{tabular}{lccccc}
\hline & $\mathrm{CV}_{Q}$ & $\mathrm{CV}_{\mathrm{NO}_{3}^{-}}$ & $\mathrm{CV}_{\mathrm{DOC}}$ & $\mathrm{CV}_{\mathrm{SRP}}$ & $\mathrm{CV}_{\mathrm{N}: \mathrm{P}}$ \\
\hline LS-Agr & $0.22 \pm 0.15$ & $0.06 \pm 0.03$ & $0.24 \pm 0.18$ & $0.55 \pm 0.47$ & $0.42 \pm 0.23$ \\
US-Agr & $2.32 \pm 0.72$ & $0.56 \pm 0.18$ & $0.45 \pm 0.15$ & $0.73 \pm 0.24$ & $1.04 \pm 0.44$ \\
US-For & $1.25 \pm 0.96$ & $0.60 \pm 0.12$ & $0.30 \pm 0.07$ & $0.74 \pm 0.20$ & $1.05 \pm 0.37$ \\
MEIS & $1.23 \pm 0.39$ & $0.73 \pm 0.12$ & $0.25 \pm 0.07$ & $0.48 \pm 0.22$ & $0.98 \pm 0.27$ \\
HAUS & $0.99 \pm 0.29$ & $0.22 \pm 0.08$ & $0.19 \pm 0.10$ & $0.65 \pm 0.27$ & $0.70 \pm 0.24$ \\
\hline
\end{tabular}

in US-Agr and US-For compared to LS-Agr, the percentage of the variation explained by the cosine function (quantified by the $R^{2}$ parameter in Table 2) was higher in US-Agr and US-For than in LS-Agr, ranging from 0.16 to 0.67 in USAgr, 0.09-0.69 in US-For and 0.03-0.15 in LS-Agr. Despite differences in mean concentration values and seasonal amplitudes, the three catchments were in phase (cf. "seasonal maximum" in Table 2) for each solute. Nitrate reached its annual maximum between Julian days 23 and 66, i.e., during a period of high flow and low temperature, whereas DOC and SRP reached their annual maxima between Julian days 236 and 282, and between 248 and 258, respectively, i.e., during a period of low flow and high temperature. Nitrate was positively and significantly correlated with discharge in all three catchments $(r=0.63-0.81$, Table 3$)$. DOC and SRP were negatively and significantly correlated with discharge only in the US-Agr catchment $(r=-0.51$ and $r=-0.65$, respectively), whereas the negative correlations and positive correlations in US-For and LS-Agr, respectively, were not significant (Table 3).

The solute export regimes for DOC and SRP exhibited similar behavior, with: (i) higher concentration in US-Agr and US-For compared to LS-Agr and (ii) a seasonal maximum in the late summer, during a period of low flow and high temperature. The export behavior of $\mathrm{NO}_{3}^{-}$was opposite, with: (i) higher concentration in LS-Agr compared to US-Agr and US-For and (ii) a seasonal maximum in the winter early-spring season, during a period of high flow and low temperature. The similar behavior of DOC and SRP, and their opposite dynamics to $\mathrm{NO}_{3}^{-}$, was confirmed by the generally negative coefficients of correlation calculated between pairs of solutes (Table 3 ).

In the downstream reaches, the observed export regimes approximately matched those expected from conservative 

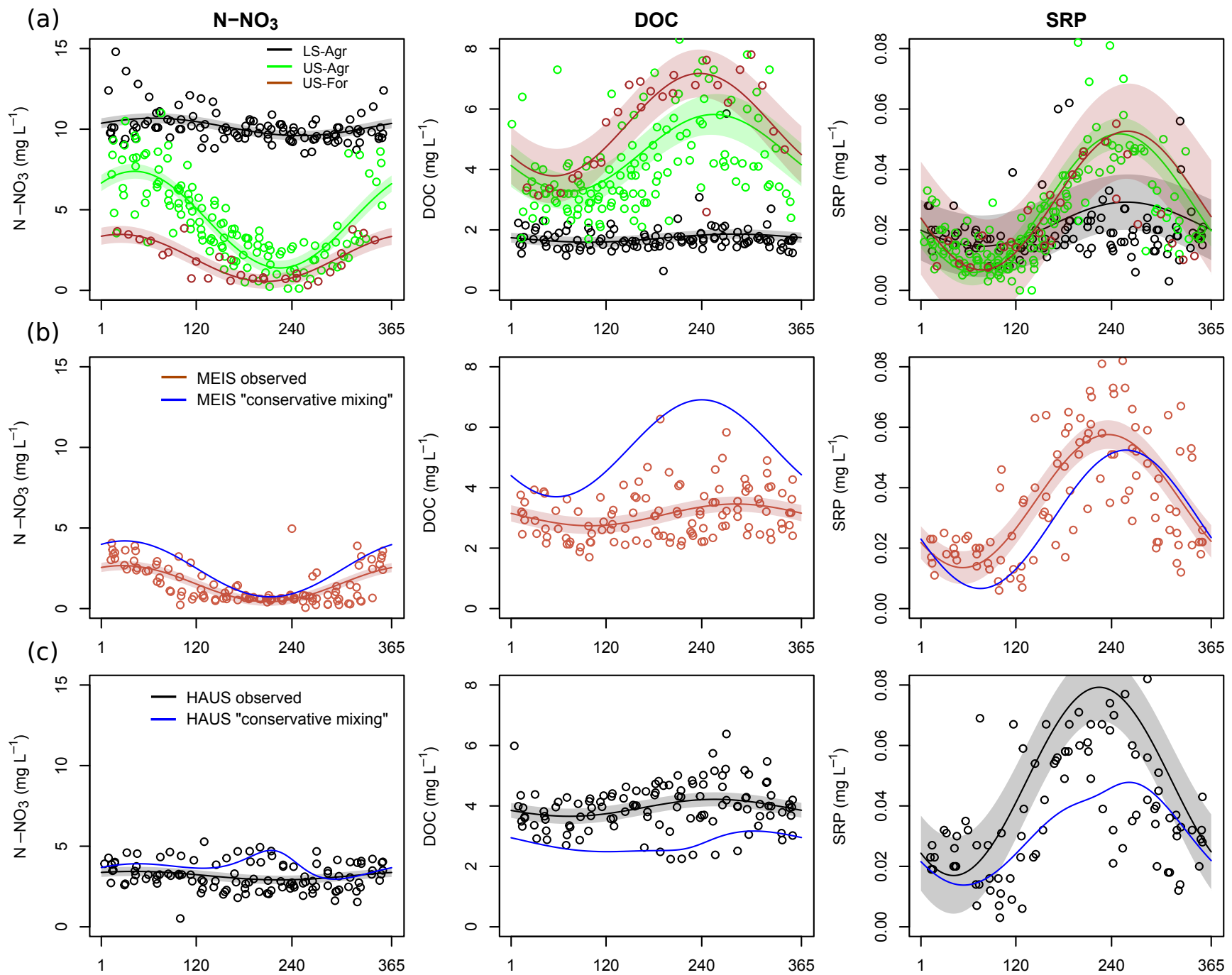

Figure 3. Intra-annual variability of nitrate $\left(\mathrm{N}-\mathrm{NO}_{3}\right)$, dissolved organic carbon (DOC) and soluble reactive phosphorus (SRP) in headwater catchments (a) and in the downstream catchments Meisdorf (b) and Hausneindorf (c). Circles represent observation data, lines represent cosine fitting and shaded areas represent $95 \%$ confidence intervals. "Conservative mixing" represents the theoretical signal that would have been obtained through mixing of headwater signals without any in-stream or point-source influence.

mixing of headwater signals for $\mathrm{NO}_{3}^{-}$(MEIS and HAUS) and SRP at MEIS, but not for DOC (MEIS and HAUS) and SRP at HAUS (Fig. 3). For $\mathrm{NO}_{3}$, the difference between observed concentrations and concentrations simulated through "conservative mixing" was on average less than $1 \mathrm{mgNL}^{-1}$ in both MEIS and HAUS. In MEIS, the relative seasonal amplitude for $\mathrm{NO}_{3}^{-}$was $72 \%$, i.e., similar to the 68 and $73 \%$ observed in US-Agr and US-For, respectively, and the seasonal maximum was reached on Julian day 27 , i.e., similar to Julian days 41 and 23 observed in US-Agr and USFor, respectively. In HAUS, the relative seasonal amplitude for $\mathrm{NO}_{3}^{-}$was small $\left(b / a=8 \%\right.$ and $\left.R^{2}=0.05\right)$ but the relatively chemostatic export regime at this location could be predicted by the "conservative mixing" of the MEIS export regime (which exhibited a large seasonal amplitude) and the
LS-Agr export regime (which exhibited a small seasonal amplitude) (Fig. 3b). For DOC, the difference between observed concentrations and concentrations simulated through "conservative mixing" was considerable (up to $3 \mathrm{mg} \mathrm{DOC}^{-1}$ ) in both MEIS and HAUS. In both MEIS and HAUS, the large relative seasonal amplitude that would have been expected from conservative mixing was not observed $(b / a$ was $12 \%$ in MEIS and $7 \%$ in HAUS, and $R^{2}$ was only 0.09 in MEIS and 0.07 in HAUS). Conservative mixing of DOC export regimes resulted in an overestimation of the observed concentrations at MEIS, and an underestimation of DOC at HAUS. For SRP, the difference between observed concentrations and concentrations simulated through conservative mixing was $<0.01 \mathrm{mg} \mathrm{SRPL}^{-1}$ in MEIS and ranged from less than $0.01 \mathrm{mg} \mathrm{SRPL}^{-1}$ in winter to up to $0.04 \mathrm{mg}$ 
Table 2. Coefficients of the cosine equation fitting to grab sampling concentration data.

\begin{tabular}{|c|c|c|c|c|c|c|}
\hline & & LS-Agr & US-Agr & US-For & MEIS & HAUS \\
\hline \multirow[t]{5}{*}{$\mathrm{N}-\mathrm{NO}_{3}^{-}$} & $a\left(\mathrm{mg} \mathrm{L}^{-1}\right)$ & 10.14 & 4.39 & 2.01 & 1.55 & 3.18 \\
\hline & $b\left(\mathrm{mg} \mathrm{L}^{-1}\right)$ & 0.54 & 3.00 & 1.46 & 1.12 & 0.26 \\
\hline & $b / a(\%)$ & 5.33 & 68.33 & 72.59 & 72.20 & 8.27 \\
\hline & Seasonal maximum (Julian day) & 66 & 42 & 24 & 27 & 42 \\
\hline & $R^{2}$ & 0.15 & 0.67 & 0.69 & 0.47 & 0.05 \\
\hline \multirow[t]{5}{*}{ DOC } & $a\left(\mathrm{mgL}^{-1}\right)$ & 1.73 & 4.55 & 5.48 & 3.10 & 3.94 \\
\hline & $b\left(\mathrm{mgL}^{-1}\right)$ & 0.13 & 1.27 & 1.69 & 0.36 & 0.28 \\
\hline & $b / a(\%)$ & 7.75 & 27.96 & 30.91 & 11.61 & 7.12 \\
\hline & Seasonal maximum (Julian day) & 282 & 254 & 237 & 284 & 256 \\
\hline & $R^{2}$ & 0.03 & 0.16 & 0.51 & 0.09 & 0.07 \\
\hline \multirow[t]{5}{*}{ SRP } & $\mathrm{a}\left(\mathrm{mg} \mathrm{L}^{-1}\right)$ & 0.02 & 0.03 & 0.03 & 0.04 & 0.05 \\
\hline & $b\left(\mathrm{mgL}^{-1}\right)$ & 0.01 & 0.02 & 0.02 & 0.02 & 0.03 \\
\hline & $b / a(\%)$ & 33.33 & 79.46 & 77.27 & 61.92 & 64.73 \\
\hline & Seasonal maximum (Julian day) & 258 & 249 & 259 & 235 & 224 \\
\hline & $R^{2}$ & 0.03 & 0.49 & 0.33 & 0.51 & 0.28 \\
\hline
\end{tabular}

Table 3. Spearman's rank correlations for discharge $(\mathrm{Q})$ and concentration parameters. Significant correlations $(p<0.05$, Holmcorrected) are in bold.

\begin{tabular}{|c|c|c|c|}
\hline LS-Agr & $Q$ & $\mathrm{NO}_{3}^{-}$ & SRP \\
\hline $\mathrm{NO}_{3}^{-}$ & 0.63 & & \\
\hline SRP & 0.11 & 0.06 & \\
\hline DOC & 0.08 & 0.05 & 0.20 \\
\hline US-Agr & $Q$ & $\mathrm{NO}_{3}^{-}$ & SRP \\
\hline $\mathrm{NO}_{3}^{-}$ & 0.81 & & \\
\hline SRP & -0.65 & -0.78 & \\
\hline DOC & -0.51 & -0.63 & 0.62 \\
\hline LS-For & $Q$ & $\mathrm{NO}_{3}^{-}$ & SRP \\
\hline $\mathrm{NO}_{3}^{-}$ & 0.70 & & \\
\hline SRP & -0.53 & -0.72 & \\
\hline DOC & -0.16 & -0.44 & 0.64 \\
\hline MEIS & $Q$ & $\mathrm{NO}_{3}^{-}$ & SRP \\
\hline $\mathrm{NO}_{3}^{-}$ & 0.79 & & \\
\hline SRP & -0.67 & -0.66 & \\
\hline DOC & 0.46 & 0.19 & 0.01 \\
\hline HAUS & $Q$ & $\mathrm{NO}_{3}^{-}$ & SRP \\
\hline $\mathrm{NO}_{3}^{-}$ & 0.18 & & \\
\hline SRP & -0.47 & -0.03 & \\
\hline DOC & -0.02 & -0.39 & 0.07 \\
\hline
\end{tabular}

$\mathrm{SRPL}^{-1}$ in summer in HAUS. In MEIS, the relative seasonal amplitude for SRP was $62 \%$, i.e., similar to the 79 and $77 \%$ observed in US-Agr and US-For, respectively, and the seasonal maximum was reached on Julian day 235 , i.e., similar to Julian days 248 and 258 observed in US-Agr and US-For, respectively. In HAUS, the relative seasonal amplitude for SRP was $65 \%$, i.e., slightly higher than would have been expected from the conservative mixing of MEIS and LS-Agr (Fig. 3c), but the seasonal maximum was reached at a date comparable to MEIS and LS-Agr (Julian day 223, vs. 235 and 257 in MEIS and LS-Agr, respectively). In HAUS, the underestimation of the relative seasonal amplitude was mainly due to underestimation of summer concentration (up to $0.04 \mathrm{mg} \mathrm{SRPL}^{-1}$; Fig. $3 \mathrm{~b}$ and c).

Results show that the N:P ratio was more variable than $\mathrm{NO}_{3}^{-}$and SRP concentrations in US-Agr, US-For, MEIS and HAUS, and was more variable than $\mathrm{NO}_{3}^{-}$but not SRP in LSAgr (Table 2). The higher variability of the $\mathrm{N}$ : $\mathrm{P}$ ratio compared to $\mathrm{NO}_{3}^{-}$and SRP in a large majority of situations is a direct consequence of the opposite seasonal dynamics of $\mathrm{NO}_{3}^{-}$and SRP in all the catchments, except LS-Agr where $\mathrm{NO}_{3}^{-}$and SRP seasonal amplitudes were small. In all the catchments, the $\mathrm{N}: \mathrm{P}$ ratio remained above the two thresholds defined to assess possible N-P co-limitation for a majority of the time. However, in two of the headwater catchments (US-Agr and US-For) and in the two downstream reaches (MEIS and HAUS), the thresholds defined to assess possible N-P co-limitation were crossed during the late summer lowflow season (Fig. 4). Considering the threshold defined by Keck and Lepori (2012), N-P co-limitation occurred $4 \%$ of the time in US-Agr, $14 \%$ in US-For, $36 \%$ in MEIS and $3 \%$ in HAUS. Considering the threshold defined by McDowell et al. (2009), N-P co-limitation occurred $17 \%$ of the time in US-Agr, $47 \%$ in US-For, $57 \%$ in MEIS and $28 \%$ in HAUS. 

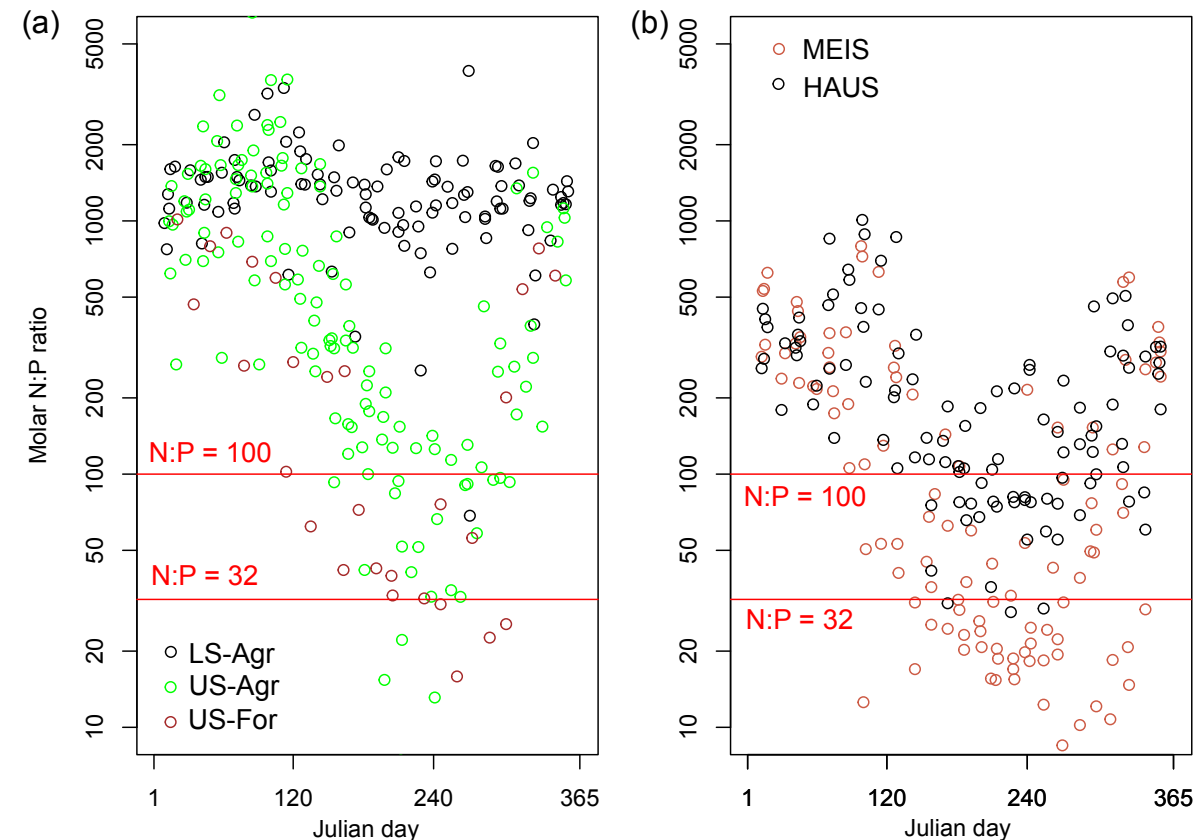

Figure 4. Intra-annual variability of the molar $\mathrm{N}: \mathrm{P}$ ratio calculated with grab sampling data in headwater catchments (a) and downstream reaches (b). The two thresholds represent $\mathrm{N}: \mathrm{P}=32 \mathrm{~mol}:$ mol and $\mathrm{N}: \mathrm{P}=100 \mathrm{~mol}: \mathrm{mol}$.
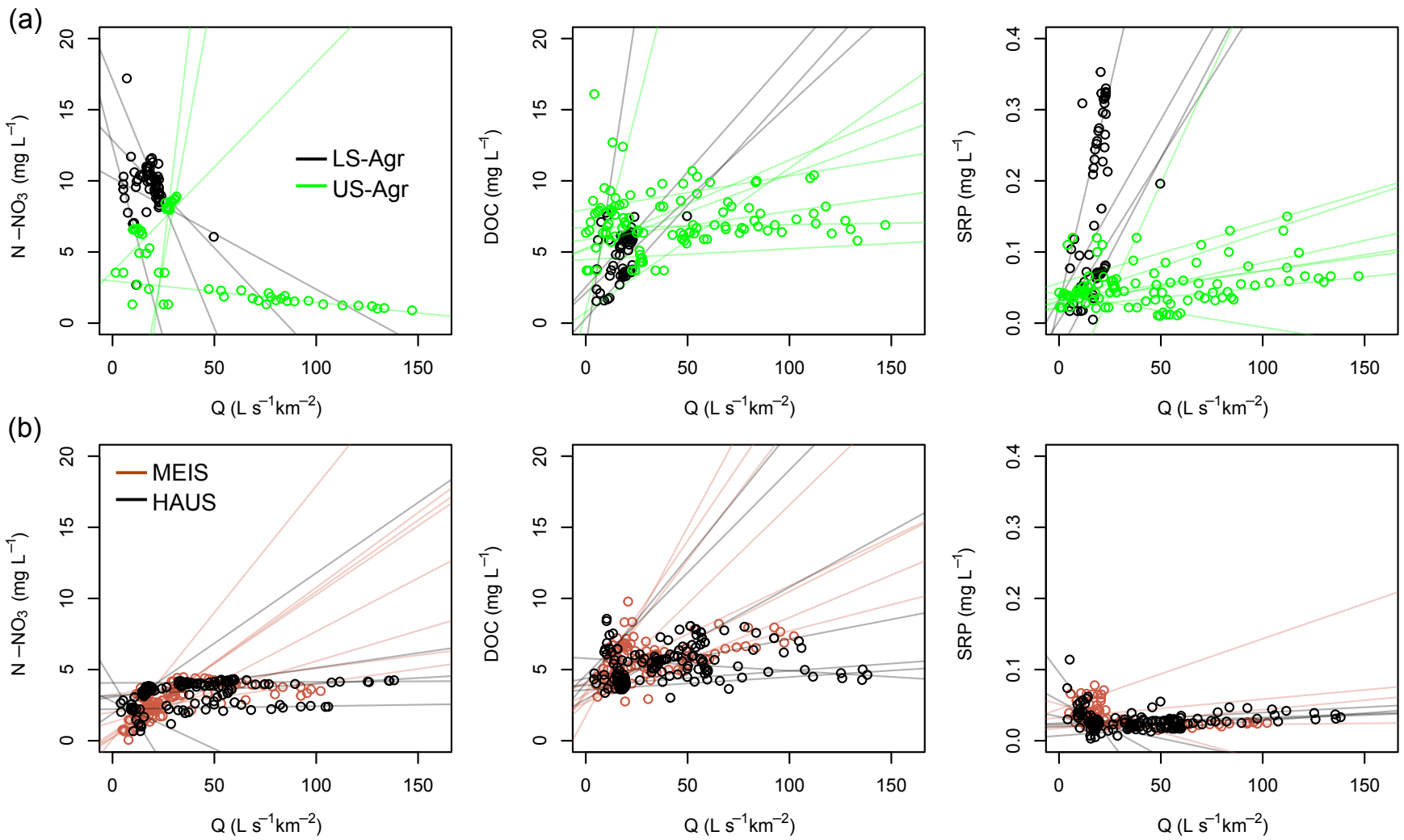

Figure 5. Concentration-discharge relationships during storm events in (a) two headwater catchments (LS-Agr, $n=4$; US-Agr, $n=8$ ) and in (b) two downstream reaches (MEIS, $n=8$; HAUS, $n=8$ ) for three solutes: nitrate-N, dissolved organic carbon (DOC) and soluble reactive phosphorus (SRP). Linear regression models were fitted to each event to quantify the proportion of events with a dilution (negative slope) or an accretion pattern (positive slope). 


\subsection{Storm event responses}

Among the three headwater catchments, high-frequency monitoring data during storm events were available in USAgr $(n=8)$ and LS-Agr $(n=4)$ (Fig. 5a). Similar to seasonal dynamics, DOC and SRP storm dynamics exhibited similar behavior with each other but opposite to $\mathrm{NO}_{3}^{-}$in a majority of situations. However, DOC and SRP exhibited a majority of accretion patterns during storm events (whereas SRP and DOC were generally negatively related to discharge on a seasonal basis) and $\mathrm{NO}_{3}^{-}$exhibited a majority of dilution patterns during storm events (whereas $\mathrm{NO}_{3}^{-}$was generally positively related to discharge on a seasonal basis) (Table 4). In addition, $\mathrm{NO}_{3}^{-}$storm dynamics appeared to be more complex in US-Agr with the occurrence of one accretion pattern and two non-significant slopes but apparent accretion patterns. It should be noted that the slopes of the $C-Q$ relationships did not always reflect the amplitude of solute concentration responses or the absolute concentrations, and slopes were generally larger in LS-Agr than in US-Agr because the former had smaller variations in discharge, arguably due to the more groundwater dominated flow regime. In general, concentration values in LS-Agr remained higher for $\mathrm{NO}_{3}^{-}$ and lower for DOC and SRP than in US-Agr (Fig. 5a), similar to concentrations from the grab sampling. In the two downstream reaches, high-frequency monitoring data during storm events were available in both MEIS $(n=8)$ and HAUS $(n=8)$ (Fig. 5b). For these two stations, accretion patterns appeared to be dominant for $\mathrm{NO}_{3}^{-}$, DOC and SRP when significant slopes were detected. One significant dilution pattern was observed for $\mathrm{NO}_{3}^{-}$in HAUS, similar to the dominant storm pattern in LS-Agr. However, non-significant slopes were dominant in a majority of events for SRP in MEIS and for all three solutes in HAUS, and among the nonsignificant slopes, apparent dilution patterns were observed for SRP in the two downstream reaches (Fig. 5b).

\section{Discussion}

Solute export regimes were interpreted in terms of land-tostream transfer and in-stream processes. Archetypal headwater catchments were selected without point sources and instream processes were deemed to have minimal effect due to the small catchment size; hence they are suitable spatial units to study $\mathrm{NO}_{3}^{-}$, DOC and SRP land-to-stream transfer processes in relatively homogeneous landscape units. The two downstream reaches were influenced by point-source contributions and potentially in-stream processes; hence the difference between export regimes observed in headwater and downstream reaches can be interpreted in terms of pointsource and in-stream influences.
Table 4. Counting of accretion and dilution patterns during storm events derived from the slope of concentration-discharge relationships $(p<0.05)$.

\begin{tabular}{lllcc}
\hline & & Dilution & Accretion & $\begin{array}{c}\text { Non-significant } \\
\text { slope }\end{array}$ \\
\hline LS-Agr & $\mathrm{N}-\mathrm{NO}_{3}^{-}$ & $3 / 4$ & $0 / 4$ & $1 / 4$ \\
& $\mathrm{DOC}$ & $0 / 4$ & $4 / 4$ & $0 / 4$ \\
& $\mathrm{SRP}$ & $0 / 4$ & $4 / 4$ & $0 / 4$ \\
\hline \multirow{2}{*}{ US-Agr } & $\mathrm{N}-\mathrm{NO}_{3}^{-}$ & $1 / 4$ & $1 / 4$ & $2 / 4$ \\
& $\mathrm{DOC}$ & $0 / 8$ & $3 / 8$ & $5 / 8$ \\
& $\mathrm{SRP}$ & $0 / 8$ & $5 / 8$ & $3 / 8$ \\
\hline \multirow{2}{*}{ MEIS } & $\mathrm{N}-\mathrm{NO}_{3}^{-}$ & $0 / 8$ & $6 / 8$ & $2 / 8$ \\
& $\mathrm{DOC}$ & $0 / 8$ & $7 / 8$ & $1 / 8$ \\
& $\mathrm{SRP}$ & $0 / 5$ & $1 / 5$ & $4 / 5$ \\
\hline \multirow{2}{*}{$\mathrm{HAUS}$} & $\mathrm{N}-\mathrm{NO}_{3}^{-}$ & $1 / 8$ & $2 / 8$ & $5 / 8$ \\
& $\mathrm{DOC}$ & $0 / 7$ & $3 / 7$ & $4 / 7$ \\
& $\mathrm{SRP}$ & $0 / 7$ & $2 / 7$ & $5 / 7$ \\
\hline
\end{tabular}

\subsection{Land-to-stream transfer}

The three archetypal headwater catchments had synchronous seasonal export regimes for each solute. Yet, the mean concentrations and the seasonal periodic amplitudes differed between catchments and solutes. We thus conclude that the same controlling factors influenced $\mathrm{NO}_{3}^{-}$, DOC and SRP export in the three catchments, but that the respective influence of these controlling factors differed according to landscape. Seasonal concentration variability is traditionally explained by the varying contribution of several conceptual compartments (end-members) with distinct chemical signatures (Aubert et al., 2013), the contribution of these compartments to stream discharge being controlled by changing hydroclimatic conditions on a seasonal basis. In addition, biogeochemical processes controlled by temperature and by the convergence of reactants in reactive hotspots such as the riparian zone (Pinay et al., 2015; Tiwari et al., 2017; Dick et al., 2015) could lead to temporal variability in the concentrations within different conceptual compartments. Thus the interplay of hydrological and biogeochemical processes controls stream $\mathrm{NO}_{3}^{-}$, DOC and SRP concentrations (Thomas et al., 2016).

Considering catchment compartments with distinct chemical signatures, we can propose a conceptual model where the seasonal variability of $\mathrm{NO}_{3}^{-}$, DOC and SRP concentrations in headwater catchments results from the mixing of two compartments. (i) A riparian compartment with low $\mathrm{NO}_{3}^{-}$ concentration (because of no fertilizer application in the riparian zone in agricultural catchments, and high denitrification potential due to hydromorphic soils in both agricultural and forested catchments, Anderson et al., 2014) and high DOC and SRP concentration (because of the shallow 
groundwater interacting with the organic soil horizons). (ii) An upslope compartment with higher $\mathrm{NO}_{3}^{-}$concentration (because of fertilization in agricultural catchments, and because of low denitrification potential in well-drained soils) and lower DOC and SRP (because of the deeper groundwater level hindering interaction with organic soil layers, Gu et al., 2017; Dupas et al., 2017). During the dry season, the contribution of the riparian compartment dominates, leading to low $\mathrm{NO}_{3}^{-}$and high DOC and SRP concentrations, whereas during the wet season, the contribution of the upslope compartment dominates, leading to high $\mathrm{NO}_{3}^{-}$and low DOC and SRP concentrations (Fig. 6). In addition to this lateral differentiation of $\mathrm{NO}_{3}^{-}$, DOC and SRP sources, a vertical distribution has previously been observed (e.g., Musolff et al., 2016a) or hypothesized (e.g., Dupas et al., 2016b) for $\mathrm{NO}_{3}^{-}$, with higher $\mathrm{NO}_{3}^{-}$concentrations in the uppermost soil layers compared to deeper soil layers, leading to higher $\mathrm{NO}_{3}^{-}$concentrations in the stream during the wet season due to activation of shallow flow pathways. The hypothesis of a vertical differentiation of concentrations controlling seasonal variations in concentrations cannot apply to DOC and SRP because these two elements are also expected to be present in higher concentrations in the uppermost soil layers and this should therefore lead to seasonal DOC and SRP variations similar to $\mathrm{NO}_{3}^{-}$. Furthermore, biogeochemical processes take place in the riparian and upslope compartments, which may lead to additional seasonal variability linked to mobilization and/or retention of $\mathrm{C}, \mathrm{N}$ and $\mathrm{P}$ sources. Biogeochemical processes are temperature dependent, and they are also influenced by residence time (Hrachowitz et al., 2016) and by the presence/absence of reactants in biogeochemical hotspots such as the riparian zone (Pinay et al., 2015; Tiwari et al., 2017; Dick et al., 2015). In this respect, high temperature and low flow velocity during the summer season (leading to high residence time in the riparian zone) provide favorable conditions for riparian denitrification and DOC and SRP mobilization. Finally, C, N and $\mathrm{P}$ also interact with each other, and several mechanisms can take place; for example increased DOC mobilization during the summer period represents a source of electron donors which can enhance denitrification (Taylor and Townsend, 2010), and DOC and SRP can be mobilized via redox processes for which $\mathrm{NO}_{3}^{-}$can act as a buffer $(\mathrm{Mu}-$ solff et al., 2016b; Gu et al., 2017).

Considering these hydrological and biogeochemical mechanisms, one can explain the different mean $\mathrm{NO}_{3}^{-}$, DOC and SRP concentrations in the three headwater catchments with: (i) higher $\mathrm{NO}_{3}^{-}$concentrations in LS-Agr due to high $\mathrm{N}$ source in agricultural land and low denitrification potential because of the absence of riparian hydromorphic soils; intermediate $\mathrm{NO}_{3}^{-}$concentration in US-Agr due to high $\mathrm{N}$ source in agricultural land but high denitrification potential because of the presence of riparian hydromorphic soils; and low $\mathrm{NO}_{3}^{-}$concentration in US-For due to low $\mathrm{N}$ source in forest land and high denitrification potential because of the presence of riparian hydromorphic soils. (ii) Lower DOC and
SRP concentrations in LS-Agr due to the deep groundwater level, inhibiting hydrological connectivity between soil C and $\mathrm{P}$ sources and the stream; and higher DOC and SRP concentrations in US-Agr and US-For due to soil-groundwater interactions in the riparian zone, leading to hydrological connectivity between soil $\mathrm{C}$ and $\mathrm{P}$ sources and the stream (Dupas et al., 2017). One can also explain the larger seasonal amplitudes in US-Agr and US-For compared to LS-Agr, linked to the presence of riparian hydromorphic soils with different hydrological (e.g., lower hydraulic conductivity) and biogeochemical properties (e.g., higher organic matter content) than upslope soils (Herndon et al., 2015) (Fig. 6).

While the seasonal concentration-discharge variability appeared clearly in the three headwater catchments, with high $\mathrm{NO}_{3}^{-}$during high flow and high DOC and SRP during low flow, these relationships seemed to be more complex during storm events. Storm event patterns (accretion or dilution) provide insight into the $\mathrm{NO}_{3}^{-}$, DOC and SRP concentrations in the flow pathways activated during storms, i.e., overland flow and shallow sub-surface flow, relative to the baseflow concentration (Dupas et al., 2016; Buda and DeWalle, 2009; Jiang et al., 2014a; Blaen et al., 2017). In both US-Agr and LS-Agr, DOC and SRP storm event dynamics exhibited a majority of accretion patterns, suggesting high $\mathrm{C}$ and $\mathrm{P}$ source in the uppermost soil layers compared to deeper soil layers (Dupas et al., 2015b; Outram et al., 2014; Bieroza and Heathwaite, 2015). Therefore, we conclude that, whereas lateral differentiation of $\mathrm{C}$ and $\mathrm{P}$ sources could explain the seasonal variability in DOC and SRP, vertical gradients of sources could explain the storm event responses. In contrast to DOC and SRP, $\mathrm{NO}_{3}^{-}$storm dynamics exhibited a majority of dilution patterns in LS-Agr and a combination of dilution and accretion pattern in US-Agr. This suggests that soil $\mathrm{NO}_{3}^{-}$concentrations in LS-Agr were lower than in the subsoil, due to plant uptake in the soil and presence of legacy $\mathrm{NO}_{3}^{-}$in the subsoil of LS-Agr (Outram et al., 2016), whereas soil $\mathrm{NO}_{3}^{-}$concentrations in US-Agr could be lower or higher than in the subsoil according to seasonal variability in soil $\mathrm{NO}_{3}^{-}$availability and possibility lateral difference between non-cultivated riparian soils and cultivated upslope soils (Dupas et al., 2016b). Therefore, both lateral and vertical gradients of $\mathrm{N}$ sources can explain variability in $\mathrm{NO}_{3}^{-}$ storm responses.

\subsection{In-stream processes and point-source contributions}

In the downstream reaches, the observed export regimes approximately matched the export regimes expected from conservative mixing of headwater signals for $\mathrm{NO}_{3}^{-}$(MEIS and HAUS) and SRP at MEIS, but not for DOC (MEIS and HAUS) and SRP at HAUS. This means that in-stream processes and point-source contributions affect $\mathrm{NO}_{3}^{-}$export regimes to a lesser degree than DOC and SRP export regimes. 
Low flow, high temperature

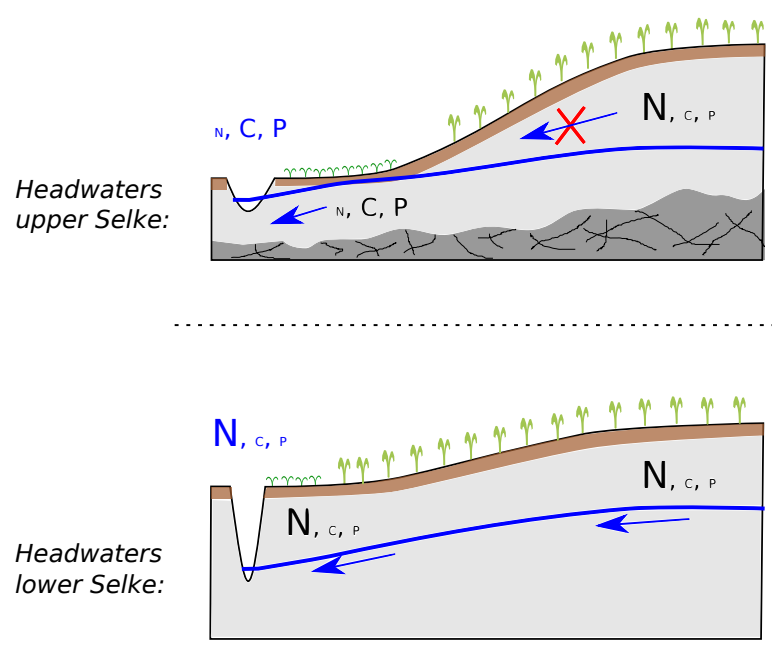

High flow, low temperature
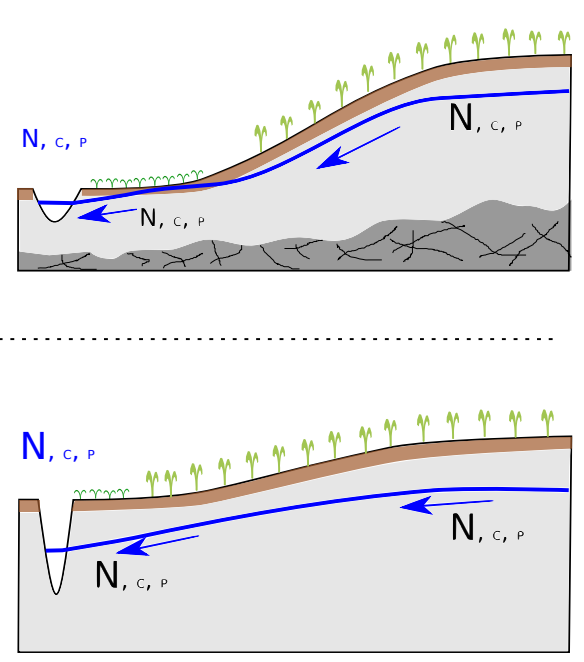

Figure 6. Conceptual model of $\mathrm{C}, \mathrm{N}$ and $\mathrm{P}$ intra-annual variability in headwater catchments in the upper Selke (archetypes US-Agr and US-For) and in the lower Selke (archetype LS-Agr). Letter size refers to the intensity of the mass flux for each solute.

For $\mathrm{NO}_{3}^{-}$, the difference between observed concentrations and concentrations estimated through the conservative mixing model was on average less than $1 \mathrm{mg} \mathrm{NL}^{-1}$ in both MEIS and HAUS, which was considered as a low absolute difference given the potentially high uncertainty in input estimation (see confidence intervals in Fig. 3 and discussion in Sect. 4.4). However, this low absolute difference represents a large relative difference in MEIS (39\% on an annual basis and up to $73 \%$ in summer) and a moderately large difference in HAUS (18\% on an annual basis and up to $63 \%$ in summer). In a previous study analyzing gross primary production and $\mathrm{NO}_{3}^{-}$assimilatory uptake in the MEIS and HAUS catchments, Rode et al. (2016a) estimated that annual in-stream $\mathrm{NO}_{3}^{-}$uptake represented $5 \%$ of $\mathrm{NO}_{3}^{-}$input in MEIS, with summer daily maxima up to $41 \%$, and $13 \%$ of $\mathrm{NO}_{3}^{-}$input in HAUS, with summer daily maxima up to $47 \%$. Whereas in HAUS the same orders of magnitude of relative $\mathrm{NO}_{3}^{-}$uptake were obtained with the balance calculation used in this study, the large relative difference in MEIS was arguably due to overestimation of $\mathrm{NO}_{3}^{-}$inputs (in relative terms) because $\mathrm{NO}_{3}^{-}$concentrations were low in this forestdominated catchment. Point-source contributions were not likely to explain the overestimation of inputs at MEIS because inputs were overestimated the most during the winter period (Fig. 3b) whereas point-source contributions to load would be expected to be highest during the summer low-flow period. To summarize, the mean concentration and the seasonal patterns observed for $\mathrm{NO}_{3}^{-}$at MEIS and HAUS were close to the expected result of conservative mixing of headwater export regimes, despite relative errors exceeding $50 \%$ when $\mathrm{NO}_{3}^{-}$concentrations were low; interestingly, conserva- tive mixing of $\mathrm{NO}_{3}^{-}$can lead to large seasonal amplitudes (72\% in MEIS, $R^{2}=0.47$ ) or to small seasonal amplitudes ( $8 \%$ in HAUS, $R^{2}=0.05$ ), depending on the seasonal export regimes of the different contributing landscape units. During storm events, the large variability in the patterns observed at MEIS and HAUS can be explained by the contribution of different landscape units, therefore no conclusion can be drawn about effects of in-stream processes and point-source contributions on $\mathrm{NO}_{3}^{-}$storm dynamics.

For DOC, the difference between observed concentrations and those estimated through the conservative mixing model was large (up to $3 \mathrm{mg} \mathrm{DOC} \mathrm{L}^{-1}$ ) in both MEIS and HAUS, and the large seasonal amplitudes observed in US-Agr and US-For were not observed in MEIS. In MEIS, conservative mixing of DOC resulted in an overestimation of the observed concentration, whereas in HAUS, DOC concentrations were underestimated. This suggests a net in-stream consumption of DOC in the upper part of the Selke river (with low nutrient and low light availability due to forest shading; Rode et al., 2016a), and a net in-stream production of DOC in the lower part of the Selke river (with high nutrient and high light availability due to absence of riparian shading; Rode et al., 2016a). The attenuation of seasonal amplitudes, increase of low DOC concentrations and decrease of high DOC concentrations suggests that the Selke river acts as a "chemostat" (Creed et al., 2015), transforming relatively chemodynamic headwater signals into more chemostatic export regimes in downstream reaches. Within two independent forested catchments $\left(\sim 40 \mathrm{~km}^{2}\right)$ of the TERENO Harz/Central German Lowland Observatory, Kamjunke et al. (2016) observed that heterotrophic bacteria respiration could consume up to $90 \%$ 
of the DOC during low-flow periods. From a national scale analysis of DOC concentration and chemical composition in the USA, Creed et al. (2015) found that, in low order rivers, labile dissolved organic matter of terrestrial origin was rapidly removed, while in higher order rivers, more aliphatic autochthonous DOC could be produced. These findings are compatible with observations in the Selke river, where an apparent DOC consumption was observed in the upstream part, close to the sources of terrestrial DOC, and an apparent DOC production was observed in the downstream part, where all labile DOC from the upstream was likely to have been consumed, but where autochthonous DOC production was made possible by higher light and nutrient availability (Rode et al., 2016a). Many other studies have found changes in DOC quantity and quality during in-stream transport (e.g., Lambert et al., 2016). During storm events, DOC dynamics exhibited a majority of accretion patterns, as expected from DOC dynamics in headwater catchments, suggesting limited in-stream or point-source influences (Raymond et al., 2016).

For SRP, the seasonal fluctuations observed at MEIS and HAUS corresponded to observations in headwater catchments free of point-sources, namely with annual SRP maxima during the late summer low-flow period. High phosphorus concentrations during low flow are commonly interpreted as resulting from undiluted point sources (Withers et al., 2014; Bowes et al., 2014, 2015; Minaudo et al., 2015), and this may lead catchment managers to target point sources as a priority to reduce eutrophication risk during the summer lowflow period. However in the present study, high SRP during low flow was also observed in headwater catchments free of point-source contributions, and this phenomenon was more prominent in the headwater catchments with the presence of riparian hydromorphic soils (US-Agr and US-For). In independent (mostly forested) catchments located in low mountain areas in Germany, Musolff et al. (2016b) have observed that summer SRP release was associated with iron release, suggesting that iron colloids could be a vector of SRP. Musolff et al. (2016b) also showed that DOC was closely associated with SRP transfer, similar to observations in US-Agr and US-For. Hence, a biogeochemical process taking place in the riparian zone could release SRP during the summer low flow in headwater catchments, mimicking a point-source signal in downstream reaches. In the MEIS catchment, which included three waste water treatment plants, the signal from the headwater catchments represented $88 \%$ of SRP during the late summer. In the lowland area, which included two waste water treatment plants, the signal from the headwater catchments represented $57 \%$ of SRP during the late summer. Therefore, attributing all summer SRP load to point-source contributions would lead to an overestimation of their contribution to phosphorus load. For a quantitative assessment of this overestimation, it would be necessary to consider in-stream exchange of SRP with particulate $\mathrm{P}$ and unreactive soluble P. During storm events, SRP accretion patterns in MEIS and HAUS were less dominant than in the headwater catchments, with a majority of non-significant concentration-discharge slopes and even occurrence of apparent dilution patterns; this reflects the contrasting effect of point-source dilution and diffuse transfer activation during storm events.

\subsection{Implications for monitoring and management}

Monitoring of the Selke river continuum from headwater catchments to downstream reaches showed that $\mathrm{NO}_{3}^{-}$, DOC and SRP concentration variability, characterized by export regime metrics, was influenced both by land-to-stream transfer processes and downstream processes such as in-stream transformations and point-source contributions. Thus, monitoring headwater catchments was necessary to disentangle both types of processes, as observed downstream export regimes may not describe well the dynamics of landto-stream transfer (Worrall et al., 2012; Minaudo et al., 2015; Temnerud et al., 2016; Baronas et al., 2017). Furthermore, both upstream processes (e.g., summer SRP release) and downstream contributions (e.g., point-source SRP contribution during summer) may lead to the same export regime (e.g., high SRP during low flow); this phenomenon creates epistemic uncertainty, which may lead to equifinality problems when calibrating catchment models to the data (Beven, 2013). This epistemic uncertainty can be effectively reduced by integrating headwater and downstream reaches in monitoring and modeling studies, as proposed by Jiang et al. (2014b). In this respect, authority monitoring programs, which typically focus on catchments greater than $100 \mathrm{~km}^{2}$, are suitable for water quality assessment but this data alone may not be enough to interpret land-to-stream transfer processes, as the signal from land transfer might be altered by downstream processes.

The results of this study also have implications for management in relation to the ecological status of rivers. First, the export regimes observed exhibit large temporal and spatial variability in $\mathrm{C}, \mathrm{N}$ and $\mathrm{P}$ dynamics: (i) the opposite seasonal dynamics of $\mathrm{NO}_{3}^{-}$and $\mathrm{SRP}$ concentrations can lead to a switch from $\mathrm{P}$ limitation to N-P co-limitation during the summer growing season and (ii) transfer from different landscape units vary in space and time. This knowledge of temporal and spatial variability is necessary for prioritizing management efforts towards $\mathrm{N}$ or $\mathrm{P}$ according to a water quality target (for which the $\mathrm{N}: \mathrm{P}$ ratio should be considered) and towards the landscape units most responsible for not attaining the water quality targets (Doody et al., 2016). Second, a comparison of seasonal export regimes in headwater and downstream reaches showed that attributing the seasonal SRP maximum during low flow only to point-source contributions could lead to ineffective management decisions if the wrong source is targeted. Finally, in-stream transformations of $\mathrm{C}, \mathrm{N}$ and $\mathrm{P}$ are typically given less consideration in management programs than the reduction of land-to-stream transfer processes. Management approaches in which land use patches would be relocated geographically in order to 
maximize in-stream retention could provide a viable addition to conventional management schemes.

\subsection{Limits and perspectives}

This study considers archetypal headwater catchments as representative of the main landscape units present in larger catchments. Although this assumption corresponds to the expert knowledge in the study area, and it has led to satisfying results in previous modeling studies (e.g., Jiang et al., 2014b), variability within landscape units (for example agricultural management practices) may exist and further research would be necessary to quantify it. This could be undertaken by considering a larger number of headwater catchments and developing empirical models such as the landscape model of Tiwari et al. (2014) combined with a stream network model. Without a quantification of uncertainty, it is difficult to quantitatively assess the effect of the different processes highlighted qualitatively in this study. For example, the small absolute difference between modeled and observed $\mathrm{NO}_{3}^{-}$at MEIS should not be interpreted in relative terms to infer in-stream $\mathrm{NO}_{3}^{-}$retention, as the concentrations involved were small compared to the uncertainty of the inputs. Another limit in this study, which prevents a quantitative assessment of processes from mass balance calculations, is the consideration of only one $\mathrm{N}$ and $\mathrm{P}$ form, and DOC as a bulk, whereas the chemical composition of $\mathrm{C}, \mathrm{N}$ and $\mathrm{P}$ compounds may be more diverse (Yates and Johnes, 2013). For example, the finding that previous $\mathrm{P}$ load apportionment studies may overestimate point-source contributions cannot be made qualitatively when only SRP data is available; a quantitative assessment would require consideration of particulate $\mathrm{P}$ and soluble unreactive $\mathrm{P}$, and exchange-transformation with SRP.

This top-down analysis study also led to new hypotheses that should be further explored via process-based studies in geochemical hotspots such as the riparian and hyporheic zones. For example, SRP release during the summer lowflow period has rarely been documented to our knowledge (see however Smolders et al., 2017). Finally, this study focused mainly on manual grab sampling data, with a limited number of high-frequency sampling of storm events; however, the storm events monitored exhibited different export regimes from seasonal variations, with for example $\mathrm{NO}_{3}^{-}$and SRP exhibiting alternatively synchronous and opposite dynamics, whereas $\mathrm{NO}_{3}^{-}$and SRP consistently had opposite dynamics on a seasonal basis. These short terms variations have implications for $\mathrm{N}$ : $\mathrm{P}$ load ratios and further research involving high-frequency sensors will allow their quantitative evaluation (Rode et al., 2016b; Blaen et al., 2017), including seasonal variability of storm event patterns (Dupas et al., 2015b; Minaudo et al., 2017).

\section{Conclusions}

The $\mathrm{C}, \mathrm{N}$ and $\mathrm{P}$ export regimes observed at the outlet of large catchments $\left(>100 \mathrm{~km}^{2}\right)$ result from the combined effects of land-to-stream transfer processes, in-stream transformations and point-source contributions. In this study, monitoring a continuum of landscape units from headwaters to downstream reaches allowed the following:

- Identifying land-to-stream transfer processes for different solutes and for the main landscape units present in the study area. A seasonal export regime for $\mathrm{NO}_{3}^{-}$opposite to those of DOC and SRP was highlighted in the three landscape types investigated. Presence/absence of riparian hydromorphic soils appeared to play a crucial role in $\mathrm{NO}_{3}^{-}$, DOC and SRP export intensity and seasonal variability.

- Identifying in-stream transformation processes and point-source contributions, highlighting that downstream signals could be strongly altered by in-stream processes (e.g., for DOC) and that natural SRP release during summer and point-source contributions could lead to similar export regimes.

Thus, this study highlights the benefit of complementary monitoring of downstream reaches and headwaters representing archetypes of landscape units, to improve understanding of processes throughout the continuum from soils to large rivers. This study also calls for a seasonal strategy to achieve water quality targets, and a landscape approach designed to maximize land and in-stream retention is advocated.

Data availability. All chemistry data are available through http:// teodoor.icg.kfa-juelich.de/overview-de.

\section{The Supplement related to this article is available online at https://doi.org/10.5194/bg-14-4391-2017-supplement.}

Competing interests. The authors declare that they have no conflict of interest.

Acknowledgements. This work was funded by TERENO (Terrestrial Environmental Observatories). The authors would like to thank all those who helped with the field and lab work, Gregor Ollesch, Ralph Meissner and the University of Applied Sciences Magdeburg.

The article processing charges for this open-access

publication were covered by a Research

Centre of the Helmholtz Association. 
Edited by: Florian Wittmann

Reviewed by: four anonymous referees

\section{References}

Ågren, A. M., Buffam, I., Cooper, D. M., Tiwari, T., Evans, C. D., and Laudon, H.: Can the heterogeneity in stream dissolved organic carbon be explained by contributing landscape elements?, Biogeosciences, 11, 1199-1213, https://doi.org/10.5194/bg-111199-2014, 2014.

Anderson, T. R., Groffman, P. M., Kaushal, S. S., and Walter, M. T.: Shallow groundwater denitrification in riparian zones of a headwater agricultural landscape, J. Environ. Qual., 43, 732-744, https://doi.org/10.2134/jeq2013.07.0303, 2014.

Aubert, A. H., Gascuel-Odoux, C., Gruau, G., Akkal, N., Faucheux, M., Fauvel, Y., Grimaldi, C., Hamon, Y., Jaffrézic, A., Lecoz-Boutnik, M., Molénat, J., Petitjean, P., Ruiz, L., and Merot, P.: Solute transport dynamics in small, shallow groundwater-dominated agricultural catchments: insights from a high-frequency, multisolute $10 \mathrm{yr}$-long monitoring study, Hydrol. Earth Syst. Sci., 17, 1379-1391, https://doi.org/10.5194/hess-171379-2013, 2013.

Baronas, J. J., Torres, M. A., Clark, K. E., and West, A. J.: Mixing as a driver of temporal variations in river hydrochemistry: 2. Major and trace element concentration dynamics in the Andes-Amazon transition, Water Resour. Res., 53, 3120-3145, https://doi.org/10.1002/2016WR019729, 2017.

Basu, N. B., Destouni, G., Jawitz, J. W., Thompson, S. E., Loukinova, N. V., Darracq, A., Zanardo, S., Yaeger, M., Sivapalan, M., Rinaldo, A., and Rao, P. S. C.: Nutrient loads exported from managed catchments reveal emergent biogeochemical stationarity, Geophys. Res. Lett., 37, L23404, https://doi.org/10.1029/2010gl045168, 2010.

Beckinsale, R. P.: River regimes, in: Water, Earth and Man, edited by: Chorley, R. J., Methuen, London, UK, 176-192, 1969.

Beusen, A. H. W., Bouwman, A. F., Van Beek, L. P. H., Mogollón, J. M., and Middelburg, J. J.: Global riverine N and P transport to ocean increased during the 20th century despite increased retention along the aquatic continuum, Biogeosciences, 13, 24412451, https://doi.org/10.5194/bg-13-2441-2016, 2016.

Beven, K.: So how much of your error is epistemic? Lessons from Japan and Italy, Hydrol. Process., 27, 1677-1680, https://doi.org/10.1002/hyp.9648, 2013

Bieroza, M. Z. and Heathwaite, A. L.: Seasonal variation in phosphorus concentration-discharge hysteresis inferred from high-frequency in situ monitoring, J. Hydrol., 524, 333-347, https://doi.org/10.1016/j.jhydrol.2015.02.036, 2015.

Bishop, K., Buffam, I., Erlandsson, M., Folster, J., Laudon, H., Seibert, J., and Temnerud, J.: Aqua Incognita: the unknown headwaters, Hydrol. Process., 22, 1239-1242, https://doi.org/10.1002/hyp.7049, 2008.

Blaen, P. J., Khamis, K., Lloyd, C., Comer-Warner, S., Ciocca, F., Thomas, R. M., MacKenzie, A. R., and Krause, S.: Highfrequency monitoring of catchment nutrient exports reveals highly variable storm-event responses and dynamic source zone activation, J. Geophys. Res.-Biogeo., 122, https://doi.org/10.1002/2017JG003904, 2017.
Botter, G., Basso, S., Rodriguez-Iturbe, I., and Rinaldo, A.: Resilience of river flow regimes, P. Natl. Acad. Sci. USA, 110, 12925-12930, https://doi.org/10.1073/pnas.1311920110, 2013.

Bouraoui, F. and Grizzetti, B.: Long term change of nutrient concentrations of rivers discharging in European seas, Sci. Total Environ., 409, 4899-4916, https://doi.org/10.1016/j.scitotenv.2011.08.015, 2011.

Bowes, M. J., Jarvie, H. P., Naden, P. S., Old, G. H., Scarlett, P. M., Roberts, C., Armstrong, L. K., Harman, S. A., Wickham, H. D., and Collins, A. L.: Identifying priorities for nutrient mitigation using river concentration-flow relationships: the Thames basin, UK, J. Hydrol., 517, 1-12, https://doi.org/10.1016/j.jhydrol.2014.03.063, 2014.

Bowes, M. J., Jarvie, H. P., Halliday, S. J., Skeffington, R. A., Wade, A. J., Loewenthal, M., Gozzard, E., Newman, J. R., and Palmer-Felgate, E. J.: Characterising phosphorus and nitrate inputs to a rural river using high-frequency concentrationflow relationships, Sci. Total Environ., 511, 608-620, https://doi.org/10.1016/j.scitotenv.2014.12.086, 2015.

Buda, A. R. and DeWalle, D. R.: Dynamics of stream nitrate sources and flow pathways during stormflows on urban, forest and agricultural watersheds in central Pennsylvania, USA, Hydrol. Process., 23, 3292-3305, https://doi.org/10.1002/hyp.7423, 2009.

Creed, I. F., McKnight, D. M., Pellerin, B. A., Green, M. B., Bergamaschi, B. A., Aiken, G. R., Burns, D. A., Findlay, S. E. G., Shanley, J. B., Striegl, R. G., Aulenbach, B. T., Clow, D. W., Laudon, H., McGlynn, B. L., McGuire, K. J., Smith, R. A., and Stackpoole, S. M.: The river as a chemostat: fresh perspectives on dissolved organic matter flowing down the river continuum, Can. J. Fish. Aquat. Sci., 72, 1272-1285, https://doi.org/10.1139/cjfas-2014-0400, 2015.

Dick, J. J., Tetzlaff, D., Birkel, C., and Soulsby, C.: Modelling landscape controls on dissolved organic carbon sources and fluxes to streams, Biogeochemistry, 122, 361-374, https://doi.org/10.1007/s10533-014-0046-3, 2015.

Doody, D. G., Withers, P. J. A., Dils, R. M., McDowell, R. W., Smith, V., McElarney, Y. R., Dunbar, M., and Daly, D.: Optimizing land use for the delivery of catchment ecosystem services, Front. Ecol. Environ., 14, 325-332, https://doi.org/10.1002/fee.1296, 2016.

Dupas, R., Delmas, M., Dorioz, J. M., Garnier, J., Moatar, F., and Gascuel-Odoux, C.: Assessing the impact of agricultural pressures on $\mathrm{N}$ and $\mathrm{P}$ loads and eutrophication risk, Ecol. Indic., 48, 396-407, https://doi.org/10.1016/j.ecolind.2014.08.007, 2015a.

Dupas, R., Tavenard, R., Fovet, O., Gilliet, N., Grimaldi, C., and Gascuel-Odoux, C.: Identifying seasonal patterns of phosphorus storm dynamics with dynamic time warping, Water Resour. Res., 51, 8868-8882, https://doi.org/10.1002/2015wr017338, 2015b.

Dupas, R., Salmon-Monviola, J., Beven, K. J., Durand, P., Haygarth, P. M., Hollaway, M. J., and Gascuel-Odoux, C.: Uncertainty assessment of a dominant-process catchment model of dissolved phosphorus transfer, Hydrol. Earth Syst. Sci., 20, 4819-4835, https://doi.org/10.5194/hess-20-4819-2016, 2016a.

Dupas, R., S., J., Musolff, A., Borchardt, D., and Rode, M.: Disentangling the influence of hydroclimatic patterns and agricultural management on river nitrate dynamics from sub-hourly to decadal time scales, Sci. Total Environ., 571, 791-800, https://doi.org/10.1016/j.scitotenv.2016.07.053, 2016b. 
Dupas, R., Mellander, P. E., Gascuel-Odoux, C., Fovet, O., McAleer, E. B., McDonald, N., Shore, M., and Jordan, P.: The role of mobilisation and delivery processes on contrasting dissolved nitrogen and phosphorus exports in groundwater fed catchments, Sci. Total Environ., 599-600, 1275-1287, 2017.

EC: Directive 2000/60/EC of the European Parliament and of the Council of 23 October 2000 establishing a framework for Community action in the field of water policy, Official Journal L 327 , 22/12/2000, 0001-0073, 2000.

Fealy, R. M., Buckley, C., Mechan, S., Melland, A., Mellander, P. E., Shortle, G., Wall, D., and Jordan, P.: The Irish Agricultural Catchments Programme: catchment selection using spatial multi-criteria decision analysis, Soil Use Manage., 26, 225-236, https://doi.org/10.1111/j.1475-2743.2010.00291.x, 2010.

Godsey, S. E., Kirchner, J. W., and Clow, D. W.: Concentrationdischarge relationships reflect chemostatic characteristics of US catchments, Hydrol. Process., 23, 1844-1864, https://doi.org/10.1002/hyp.7315, 2009.

Grathwohl, P., Rugner, H., Wohling, T., Osenbruck, K., Schwientek, M., Gayler, S., Wollschlager, U., Selle, B., Pause, M., Delfs, J. O., Grzeschik, M., Weller, U., Ivanov, M., Cirpka, O. A., Maier, U., Kuch, B., Nowak, W., Wulfmeyer, V., WarrachSagi, K., Streck, T., Attinger, S., Bilke, L., Dietrich, P., Fleckenstein, J. H., Kalbacher, T., Kolditz, O., Rink, K., Samaniego, L., Vogel, H. J., Werban, U., and Teutsch, G.: Catchments as reactors: a comprehensive approach for water fluxes and solute turnover, Environ. Earth Sci., 69, 317-333, https://doi.org/10.1007/s12665-013-2281-7, 2013.

Gu, S., Gruau, G., Dupas, R., Rumpel, C., Creme, A., Fovet, O., Gascuel-Odoux, C., Jeanneau, L., Humbert, G., and Petitjean, P.: Release of dissolved phosphorus from riparian wetlands: evidence for complex interactions among hydroclimate variability, topography and soil properties, Sci. Total Environ., 598, 421431, https://doi.org/10.1016/j.scitotenv.2017.04.028, 2017.

Hartmann, A., Kobler, J., Kralik, M., Dirnböck, T., Humer, F., and Weiler, M.: Model-aided quantification of dissolved carbon and nitrogen release after windthrow disturbance in an Austrian karst system, Biogeosciences, 13, 159-174, https://doi.org/10.5194/bg-13-159-2016, 2016.

Herndon, E. M., Dere, A. L., Sullivan, P. L., Norris, D., Reynolds, B., and Brantley, S. L.: Landscape heterogeneity drives contrasting concentration-discharge relationships in shale headwater catchments, Hydrol. Earth Syst. Sci., 19, 3333-3347, https://doi.org/10.5194/hess-19-3333-2015, 2015.

Hrachowitz, M., Benettin, P., van Breukelen, B. M., Fovet, O., Howden, N. J. K., Ruiz, L., van der Velde, Y., and Wade, A. J.: Transit times - the link between hydrology and water quality at the catchment scale, WIREs Water, 3, 629-657, https://doi.org/10.1002/wat2.1155, 2016.

Humbert, G., Jaffrezic, A., Fovet, O., Gruau, G., and Durand, P.: Dry-season length and runoff control annual variability in stream DOC dynamics in a small, shallow groundwater-dominated agricultural watershed, Water Resour. Res., 51, 7860-7877, https://doi.org/10.1002/2015wr017336, 2015.

Jiang, R., Hatano, R., Zhao, Y., Kuramochi, K., Hayakawa, A., Woli, K. P., and Shimizu, M.: Factors controlling nitrogen and dissolved organic carbon exports across timescales in two watersheds with different land uses, Hydrol. Process., 28, 5105-5121, https://doi.org/10.1002/hyp.9996, 2014a.
Jiang, S. Y., Jomaa, S., and Rode, M.: Modelling inorganic nitrogen leaching in nested mesoscale catchments in central Germany, Ecohydrology, 7, 1345-1362, https://doi.org/10.1002/eco.1462, 2014b.

Kamjunke, N., Oosterwoud, M. R., Herzsprung, P., and Tittel, J.: Bacterial production and their role in the removal of dissolved organic matter from tributaries of drinking water reservoirs, Sci. Total Environ., 548, 51-59, https://doi.org/10.1016/j.scitotenv.2016.01.017, 2016.

Keck, F. and Lepori, F.: Can we predict nutrient limitation in streams and rivers?, Freshwater Biol., 57, 1410-1421, https://doi.org/10.1111/j.1365-2427.2012.02802.x, 2012.

Lambert, T., Teodoru, C. R., Nyoni, F. C., Bouillon, S., Darchambeau, F., Massicotte, P., and Borges, A. V.: Alongstream transport and transformation of dissolved organic matter in a large tropical river, Biogeosciences, 13, 2727-2741, https://doi.org/10.5194/bg-13-2727-2016, 2016.

Laudon, H., Berggren, M., Agren, A., Buffam, I., Bishop, K., Grabs, T., Jansson, M., and Kohler, S.: Patterns and dynamics of dissolved organic carbon (DOC) in boreal streams: the role of processes, connectivity, and scaling, Ecosystems, 14, 880-893, https://doi.org/10.1007/s10021-011-9452-8, 2011.

McDowell, R. W., Larned, S. T., and Houlbrooke, D. J.: Nitrogen and phosphorus in New Zealand streams and rivers: control and impact of eutrophication and the influence of land management, New Zeal. J. Mar. Fresh, 43, 985-995, 2009.

McGonigle, D. F., Burke, S. P., Collins, A. L., Gartner, R., Haft, M. R., Harris, R. C., Haygarth, P. M., Hedges, M. C., Hiscock, K. M., and Lovett, A. A.: Developing demonstration test catchments as a platform for transdisciplinary land management research in England and Wales, Environ. Sci.-Proc. Imp., 16, 1618-1628, https://doi.org/10.1039/c3em00658a, 2014.

Minaudo, C., Meybeck, M., Moatar, F., Gassama, N., and Curie, F.: Eutrophication mitigation in rivers: 30 years of trends in spatial and seasonal patterns of biogeochemistry of the Loire River (1980-2012), Biogeosciences, 12, 2549-2563, https://doi.org/10.5194/bg-12-2549-2015, 2015.

Minaudo, C., Dupas, R., Gascuel-Odoux, C., Fovet, O., Mellander, P.-E., Jordan, P., Shore, M., and Moatar, F.: Nonlinear empirical modeling to estimate phosphorus exports using continuous records of turbidity and discharge, Water Resour. Res., 53, https://doi.org/10.1002/2017WR020590, 2017.

Musolff, A., Schmidt, C., Selle, B., and Fleckenstein, J. H.: Catchment controls on solute export, Adv. Water Resour., 86, 133-146, https://doi.org/10.1016/j.advwatres.2015.09.026, 2015.

Musolff, A., Schmidt, C., Rode, M., Lischeid, G., Weise, S. M., and Fleckenstein, J. H.: Groundwater head controls nitrate export from an agricultural lowland catchment, Adv. Water Resour., 96, 95-107, https://doi.org/10.1016/j.advwatres.2016.07.003, 2016 .

Musolff, A., Selle, B., Buettner, O., Opitz, M., and Tittel, J.: Unexpected release of phosphate and organic carbon to streams linked to declining nitrogen depositions, Glob. Change Biol., 23, 1-11, https://doi.org/10.1111/gcb.13498, 2016b.

Musolff, A., Fleckenstein, J. H., Rao, P. S. C., and Jawitz, J. W. Emergent archetype patterns of coupled hydrologic and biogeochemical responses in catchments, Geophys. Res. Lett., 44, 4143-4151, https://doi.org/10.1002/2017gl072630, 2017. 
Outram, F. N., Lloyd, C. E. M., Jonczyk, J., Benskin, C. McW. H., Grant, F., Perks, M. T., Deasy, C., Burke, S. P., Collins, A. L., Freer, J., Haygarth, P. M., Hiscock, K. M., Johnes, P. J., and Lovett, A. L.: High-frequency monitoring of nitrogen and phosphorus response in three rural catchments to the end of the 20112012 drought in England, Hydrol. Earth Syst. Sci., 18, 34293448, https://doi.org/10.5194/hess-18-3429-2014, 2014.

Outram, F. N., Cooper, R. J., Sünnenberg, G., Hiscock, K. M., and Lovett, A. A.: Antecedent conditions, hydrological connectivity and anthropogenic inputs: factors affecting nitrate and phosphorus transfers to agricultural headwater streams, Sci. Total Environ., 545-546, 184-199, https://doi.org/10.1016/j.scitotenv.2015.12.025, 2016.

Pinay, G., Peiffer, S., De Dreuzy, J. R., Krause, S., Hannah, D. M., Fleckenstein, J. H., Sebilo, M., Bishop, K., and Hubert-Moy, L.: Upscaling nitrogen removal capacity from local hotspots to low stream orders' drainage basins, Ecosystems, 18, 1101-1120, https://doi.org/10.1007/s10021-015-9878-5, 2015.

Raymond, P. A., Saiers, J. E., and Sobczak, W. V.: Hydrological and biogeochemical controls on watershed dissolved organic matter transport: pulse-shunt concept, Ecology, 97, 5-16, https://doi.org/10.1890/14-1684.1, 2016.

Rode, M., Halbedel, S., Anis, M., Borchardt, D., and Weitere, M.: Continuous in-stream assimilatory nitrate uptake from high frequency sensor measurements, Environ. Sci. Technol., 50, 56855694, https://doi.org/10.1021/acs.est.6b00943, 2016a.

Rode, M., Wade, A. J., Cohen, M. J., Hensley, R. T., Bowes, M. J., Kirchner, J. W., Arhonditsis, G. B., Jordan, P., Kronvang, B., Halliday, S. J., Skeffington, R. A., Rozemeijer, J. C., Aubert, A. H., Rinke, K., and Jomaa, S.: Sensors in the stream: the highfrequency wave of the present, Environ. Sci. Technol., 50, 10297-10307, https://doi.org/10.1021/acs.est.6b02155, 2016 b.

Salmon-Monviola, J., Moreau, P., Benhamou, C., Durand, P., Merot, P., Oehler, F., and Gascuel-Odoux, C.: Effect of climate change and increased atmospheric $\mathrm{CO}_{2}$ on hydrological and nitrogen cycling in an intensive agricultural headwater catchment in western France, Climatic Change, 120, 433-447, https://doi.org/10.1007/s10584-013-0828-y, 2013.

Sardans, J., Rivas-Ubach, A., and Penuelas, J.: The elemental stoichiometry of aquatic and terrestrial ecosystems and its relationships with organismic lifestyle and ecosystem structure and function: a review and perspectives, Biogeochemistry, 111, 1-39, https://doi.org/10.1007/s10533-011-9640-9, 2012.

Seitzinger, S. P., Mayorga, E., Bouwman, A. F., Kroeze, C., Beusen, A. H. W., Billen, G., Van Drecht, G., Dumont, E., Fekete, B. M., Garnier, J., and Harrison, J. A.: Global river nutrient export: a scenario analysis of past and future trends, Global Biogeochem. Cy., 24, GB0A08, https://doi.org/10.1029/2009gb003587, 2010.

Smolders, E., Baetens, E., Verbeek, M., Nawara, S., Diels, J., Verdievel, M., Peeters, B., De Cooman, W., and Baken, S.: Internal loading and redox cycling of sediment iron explain reactive phosphorus concentrations in lowland rivers, Environ. Sci. Technol., 51, 2584-2592, https://doi.org/10.1021/acs.est.6b04337, 2017.

Taylor, P. G. and Townsend, A. R.: Stoichiometric control of organic carbon-nitrate relationships from soils to the sea, Nature, 464, 1178-1181, https://doi.org/10.1038/nature08985, 2010.
Temnerud, J., von Brömssen, C., Fölster, J., Buffam, I., Andersson, J.-O., Nyberg, L., and Bishop, K.: Map-based prediction of organic carbon in headwater streams improved by downstream observations from the river outlet, Biogeosciences, 13, 399-413, https://doi.org/10.5194/bg-13-399-2016, 2016.

Thomas, Z., Abbott, B. W., Troccaz, O., Baudry, J., and Pinay, G.: Proximate and ultimate controls on carbon and nutrient dynamics of small agricultural catchments, Biogeosciences, 13, 18631875, https://doi.org/10.5194/bg-13-1863-2016, 2016.

Thompson, S. E., Basu, N. B., Lascurain, J., Jr., Aubeneau, A., and Rao, P. S. C.: Relative dominance of hydrologic versus biogeochemical factors on solute export across impact gradients, Water Resour. Res., 47, W00J05, https://doi.org/10.1029/2010wr009605, 2011.

Tiwari, T., Laudon, H., Beven, K., and Agren, A. M.: Downstream changes in DOC: inferring contributions in the face of model uncertainties, Water Resour. Res., 50, 514-525, https://doi.org/10.1002/2013wr014275, 2014.

Tiwari, T., Lidman, F., Laudon, H., Lidberg, W., and Agren, A.: GIS-based prediction of stream chemistry using landscape composition, wet areas and hydrological flow pathways, J. Geophys. Res.-Biogeo., 122, 65-79, https://doi.org/10.1002/2016JG003399, 2017.

Wall, D., Jordan, P., Melland, A. R., Mellander, P. E., Buckley, C., Reaney, S. M., and Shortie, G.: Using the nutrient transfer continuum concept to evaluate the European Union Nitrates Directive National Action Programme, Environ. Sci. Policy, 14, 664-674, https://doi.org/10.1016/j.envsci.2011.05.003, 2011.

Withers, P. J. A., Jordan, P., May, L., Jarvie, H. P., and Deal, N. E.: Do septic tank systems pose a hidden threat to water quality?, Front. Ecol. Environ., 12, 123-130, https://doi.org/10.1890/130131, 2014.

Wollschlager, U., Attinger, S., Borchardt, D., Brauns, M., Cuntz, M., Dietrich, P., Fleckenstein, J. H., Friese, K., Friesen, J., and al., e.: The Bode hydrological observatory: a platform for integrated, interdisciplinary hydro-ecological research within the TERENO Harz/Central German Lowland Observatory, Environ. Earth Sci., 76, 29, https://doi.org/10.1007/s12665-016-6327-5, 2016.

Worrall, F., Davies, H., Bhogal, A., Lilly, A., Evans, M., Turner, K., Burt, T., Barraclough, D., Smith, P., and Merrington, G.: The flux of DOC from the UK - Predicting the role of soils, land use and net watershed losses, J. Hydrol., 448, 149-160, https://doi.org/10.1016/j.jhydrol.2012.04.053, 2012.

Yates, C. A. and Johnes, P. J.: Nitrogen speciation and phosphorus fractionation dynamics in a lowland Chalk catchment, Sci. Total Environ., 444, 466-479, https://doi.org/10.1016/j.scitotenv.2012.12.002, 2013.

Zacharias, S., Bogena, H., Samaniego, L., Mauder, M., Fuss, R., Putz, T., Frenzel, M., Schwank, M., Baessler, C., ButterbachBahl, K., Bens, O., Borg, E., Brauer, A., Dietrich, P., Hajnsek, I., Helle, G., Kiese, R., Kunstmann, H., Klotz, S., Munch, J. C., Papen, H., Priesack, E., Schmid, H. P., Steinbrecher, R., Rosenbaum, U., Teutsch, G., and Vereecken, H.: A network of terrestrial environmental observatories in Germany, Vadose Zone J., 10, 955-973, https://doi.org/10.2136/vzj2010.0139, 2011. 